\title{
Macroprudential Policy and Financial (In)Stability Analysis in the Russian Federation ${ }^{1}$
}

\author{
Mikhail Andreev, Bank of Russia \\ andreevmyu@cbr.ru \\ M. Udara Peiris, National Research University Higher School of Economics \\ upeiris@hse.ru \\ Aleksandr Shirobokov, National Research University Higher School of Economics \\ ashirobokov@hse.ru \\ Dimitrios P. Tsomocos, Saïd Business School and St Edmund Hall, \\ University of Oxford; National Research University Higher School of Economics \\ dimitrios.tsomocos@sbs.ox.ac.uk
}

We study a small open economy New Keynesian model calibrated to the Russian economy with a banking system that trades secured and unsecured debt. Firms endogenously default on their unsecured debt obligations over the business cycle. We examine the effectiveness of four alternative countercyclical policies that respond to the growth in unsecured credit in the economy. The lean-against-the-wind monetary policy is the most effective in simultaneously affecting the real economy and stabilizing the banking system in response to both oil price and total factor productivity shocks. The countercyclical deposit reserve requirement was found to play a stabilizing role following an oil shock, while the countercyclical capital adequacy requirement helped to stabilize the banking system after a total factor productivity shock.

Keywords: business cycles, small open economy, emerging markets, commodity prices, financial stability, macroprudential policy,

Russian economy

JEL Codes: F34, G15, G18
Citation: Andreev, M., Peiris, M. U., Shirobokov, A. and Tsomocos, D. P. (2019). Macroprudential Policy and Financial (In)Stability Analysis in the Russian Federation. Russian Journal of Money and Finance, 78(3), pp. 3-37.

doi: $10.31477 /$ rjmf.201903.03

\footnotetext{
${ }^{1}$ We would like to thank the participants in the 2019 Bank of Russia International Research Conference 'Macroprudential Policy Effectiveness: Theory and Practice', Bank for International Settlements 12th Annual Workshop of the Asian Research Network at the Reserve Bank of Australia, 2019 Surrey DSGE workshop, and 2nd HSE ILMA workshop, as well as Anthony Brassil, Valery Charnavoki, Mikhail Dmitriev, Vasco Gabriel, Christian Julliard, Madina Karamysheva, Christoffer Koch, Nikos Kokonas, Paul Levine, Oxana Malakhovskaya, Juan Francisco Martínez, Maxim Nikitin, Sergey Pekarskii, Assaf Razin, Sergey Seleznev, Daniil Shestakov, Andrey Sinyakov, Konstantin Styrin, Kieran Walsh, an anonymous referee, and especially Ekaterina Kazakova. The contribution of Peiris, Shirobokov, and Tsomocos to this study was funded by the Basic Research Program at the National Research University Higher School of Economics (HSE) and by the Russian Academic Excellence Project 5-100.
} 


\section{Introduction}

The optimal interaction between macroprudential and monetary policies still remains an important challenge globally for policy. In Russia, the economic difficulties from late 2014 onward have heightened the need to complement existing monetary and microprudential tools with additional policies, that can help stabilize the financial system. In this paper, we study the impact of various candidate macroprudential policies within a New Keynesian model with a banking system and where default on unsecured debt amplifies the business cycle effect of shocks. We find that a monetary policy that leans-against-thewind (LAW) in reacting to unsecured credit growth can dampen the effects of commodity price shocks.

We study a small open commodity-exporting New Keynesian DSGE model with price and wage rigidities, firms, and banks which are subject to capital requirements. Firms issue secured and unsecured debt in the model, and can renegotiate their unsecured debt obligations to obtain a haircut (default) from the banks. Firms' default rates vary endogenously over the business cycle. Macroprudential policy addresses the pecuniary externalities resulting from binding collateral constraints and defaults on unsecured debt. Two-period lived risk-averse banks combine household deposits with equity received from households and extend secured and unsecured loans to firms. Banks are subject to microprudential regulation in the form of capital adequacy ratios.

The significance of unsecured credit in Russia is reflected in the importance of credit lines as a source of liquidity for firms and loans to early-stage firms which have limited collateral. Table 6 in the Appendix (see p. 37) displays point estimates for different types of loans. According to this partial data ${ }^{2}$ only $17-18 \%$ of corporate loans have real estate as collateral. 56-75\% of loans are uncollateralized or have financial collateral. The importance of 'risky' borrowers in evaluations of financial stability was central to the policy debate in the US following the crisis of 2007-2008. Aikman et al. (2019) describe how the aggregate loan-to-value (LTV) ratio on mortgages remained stable in the years leading up to the US crisis, but with an increase in the concentration of debt among riskier borrowers, while debt buildup among heavily indebted borrowers was not being adequately picked up (see Eichner et al., 2013).

Our closest methodological precursors are Peiris and Tsomocos (2015), De Walque et al. (2010), Goodhart et al. (2018), and Walsh (2016). In the latter two papers, the marginal cost of default depends on the debt-to-capital ratio and the level of wealth respectively, so the propensity to default depends on business cycle fluctuations. We follow this notion here by introducing a macrovariable that governs the marginal cost of renegotiating debt (default), termed

\footnotetext{
${ }^{2}$ We were able to obtain information on this for only two of the 12 largest Russian banks.
} 
'credit conditions'. This reflects the changing motivations and incentives of debtors to make the necessary sacrifices to repay their obligations, as emphasized by Roch and Uhlig (2016). We introduce optimizing banks subject to regulatory requirements along the lines of Tsomocos (2003) and Martinez and Tsomocos (2018).

Nachane et al. (2006), Ghosh (2008), Gavalas (2015), and Gambacorta and Shin (2016) show that the more restrictive its rules (in particular, capital requirements), the greater contractionary effect a monetary policy may have. However, strict macroprudential regulation may have the opposite effect on banks' risk-taking. Gale (2010) suggests that excessively restrictive capital requirements may encourage banks to take higher risks in order to earn higher expected profits. In this case, when monetary authorities increase interest rates, this may not have a contractionary effect on the credit market, and banks will form highly risky loan portfolios as the costs of funding increase. As a result, defaults by risky firms may create financial instability. ${ }^{3}$

In Section 3.4 we turn to candidate macroprudential policy tools that aim to stabilize the economy. We consider LAW, deposit requirements, capital adequacy, and LTV policies that rely on the deviation of unsecured loans from steady state. In line with Cúrdia and Woodford (2010) and Gourio et al. (2018), among others, we show that a LAW policy can potentially mitigate the effect of shocks to the international oil price and total factor productivity (TFP). We also show that a countercyclical deposit reserve requirement, like a liquidity prudential requirement, may be helpful following an oil price shock (for the potential benefits of liquidity prudential requirements see Berben et al., 2010), while a countercyclical LTV policy may be useful following a TFP shock.

As far as studies on Russia are concerned, our paper is closely related to Kozlovtceva et al. (2019), which extends the model of Kreptsev and Seleznev (2017) to study various monetary policy rules and finds that LAW monetary policy serves to stabilize output. The authors show that, when oil price volatility is relatively high and the monetary authority is tending towards minimizing variation in GDP, inflation, and the credit-to-GDP ratio, then a LAW policy is preferable. However, if oil price volatility is relatively small and smoothing the credit cycle is not currently a goal, then a LAW policy does not perform well. The authors also indicate that, under countercyclical fiscal policies, there is a significant reduction in the efficiency gap between inflation targeting and LAW monetary policy in macroeconomic stabilization. Whereas Kozlovtceva et al. (2019) use total credit to GDP in the Taylor Rule, we use the level of unsecured credit. We use unsecured credit because it is a better

\footnotetext{
${ }^{3}$ It is also worth noting that it is not only macroprudential regulation that has an impact on the monetary transmission mechanism. According to Borio and Zhu (2012) and de Moraes et al. (2016), the monetary policy stance itself can affect the optimal level of macroprudential regulation.
} 
metric of financial fragility in our model. We do not normalize by GDP as we focus on the stationary growth path of the economy, posing the question of whether stabilizing unsecured credit is a way to stabilize output fluctuations. ${ }^{4}$ Malakhovskaya and Minabutdinov (2014) examine the impact of structural shocks on business cycle fluctuations and show that the risk premium shock and commodity export shock jointly capture the financial crises of 2009 in Russia, while Polbin (2014) studies the stabilizing role of different fiscal policies. Ivashchenko (2013) allows for endogenous default by firms and shows in an estimated model that inflation dynamics in Russia were primarily driven by the actions of the government. He also argues that the influence of the financial sector of the Russian economy on the real sector is weak.

Section 2 presents the model. Section 3 presents the quantitative results of the model and compares the effects of alternative policies in response to shocks. Section 4 conducts a sensitivity analysis given various parameterizations of the policy rules. Finally, Section 5 presents concluding remarks.

\section{A New Keynesian small open economy model with a banking sector}

\subsection{Circular flow of funds}

Households which are infinitely lived own capital producers, nontradable goods producers, banks and other firms. They save by making deposits at banks and acquiring domestic and foreign bonds. Wholesale producers require funding to invest in physical capital in order to produce intermediate non-tradable goods. Unsecured loans are repaid next period, a condition which firms may renegotiate and on which they may obtain a haircut. Secured borrowing is subject to a collateral constraint. Banks combine households' deposits with their equity and lend to wholesale producers. Loan origination requires banks to satisfy capital adequacy requirements imposed by the monetary authority. The tradable sector consists of importers and exogenous oil export. Importers import intermediate goods from the rest of the world and sell them to capital producers, who use them as an input for the production of capital together with undepreciated capital. Oil reserves belong to the government, and it receives all the oil revenue. The monetary authority sets the nominal interest rate on domestic bonds. The fiscal authority spends its revenues on nontradable and imported goods. The circular flow of funds is summarised in Figure 1.

\footnotetext{
${ }^{4}$ In practice, credit to trend GDP would be a better measure to use.
} 
Figure 1. Circular flows diagram

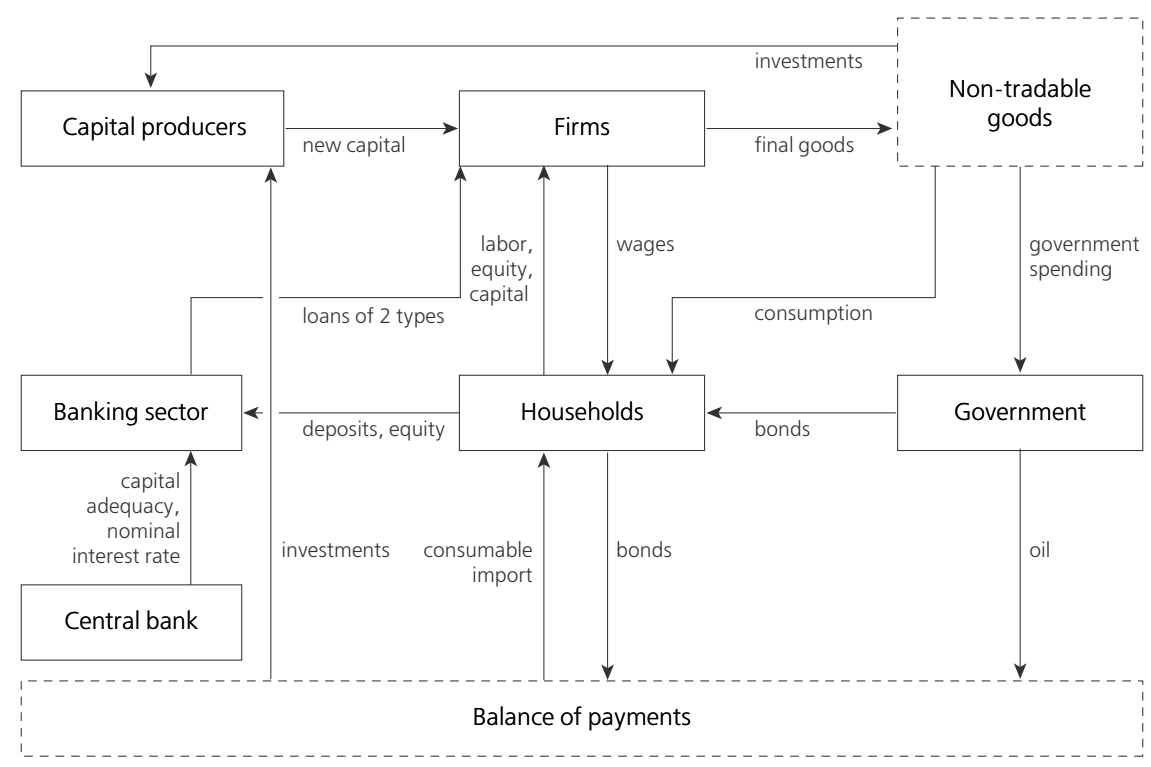

\subsection{Households}

Households are infinitely lived and consume a bundle $\left(c_{t}\right)$ consisting of domestically produced goods $\left(c_{N, t}\right)$ and imported goods $\left(c_{T, t}\right)$. Labour $\left(l_{t}^{h}\right)$ is supplied monopolistically at a wage $\left(w_{t}\right)$ that can be stochastically chosen and updated. ${ }^{5}$

Households own all firms (wholesale and intermediate producers, retailers, and capital producers) and banks in the economy and receive profits from them. Equity is invested in banks and wholesale producers ( $e_{t}^{\text {bank }}$ and $e_{t}^{w, t o t a l}$ respectively). Equity received by the wholesale producers is composed of the net equity $\left(e_{t}^{w}\right)$ and undepreciated capital that households receive from firms ending operations in the current period $\left((1-\tau) p_{t}^{K} k_{t}^{w}\right)$. Households also save via bank deposits $\left(d_{t}^{h}\right)$, foreign bonds $\left(B_{t}^{f}\right)$, and domestic government bonds $\left(B_{t}^{g, h}\right)$.

Households maximize their discounted expected utility subject to their budget constraint:

$$
\begin{aligned}
\max _{c_{T, t}, c_{N, t}, e_{t}^{w, t o t a l}, e_{t}^{\text {bank }}, d_{t+1}^{h}, w_{t}, B_{t}^{f}, B_{t}^{g, h}} \frac{\left(c_{0}^{h}\right)^{1-\sigma}}{1-\sigma}-\theta^{h} \frac{\left(l_{0}^{h}\right)^{1+\gamma^{h}}}{1+\gamma^{h}} \\
+\mathbb{E}_{0} \sum_{t=1}^{\infty}\left(\beta_{t-1}^{h}\right)^{t}\left[\frac{\left(c_{t}^{h}\right)^{1-\sigma}}{1-\sigma}-\theta^{h} \frac{\left(l_{t}^{h}\right)^{1+\gamma^{h}}}{1+\gamma^{h}}\right] .
\end{aligned}
$$

\footnotetext{
${ }^{5}$ We follow Erceg et al. (2000) in defining wage rigidity and monopolistic competition in the labour market.
} 
The consumption bundle is:

$$
c_{t}=A^{c}\left[\left(\phi^{h}\right)^{\frac{1}{v_{c}}} c_{N, t}^{\frac{v_{c}-1}{v_{c}}}+\left(1-\phi^{h}\right)^{\frac{1}{v_{c}}} c_{T, t}^{\frac{v_{c}-1}{v_{c}}}\right]^{\frac{v_{c}}{v_{c}-1}},
$$

where $\phi^{h}$ is the share of domestic goods in the consumption basket and $v_{c}$ is the elasticity of substitution between domestic and foreign consumption goods.

The budget constraint of a household is

$$
\begin{aligned}
d_{t+1}^{h}+ & p_{t}^{i m p} c_{T, t}+c_{N, t}+e_{t}^{w, t o t a l}+e_{t}^{\text {bank }}+Q_{t} B_{t}^{f}+B_{t}^{g, h} \\
\leq & \left(1+r_{t}^{d}\right) d_{t}^{h}+Q_{t} B_{t-1}^{f}\left(1+r_{t}^{f}\right)+B_{t-1}^{g, h}\left(1+r_{t}^{b}\right)+w_{t} l_{t}^{h} \\
& \quad+\left(1-\theta^{w}\right) \bar{\Pi}_{t}^{w}+\theta^{w} \underline{\Pi}_{t}^{w}+\Pi_{t}^{\text {bank }}+\Pi_{t}^{c a p}+\Pi_{t}^{r e t}-A_{t}^{s},
\end{aligned}
$$

where $Q_{t}$ is the real exchange rate, $p_{t}^{i m p}$ is the domestic price of imported goods, $e_{t}^{w, t o t a l}=\left(e_{t}^{w}+(1-\tau) p_{t}^{K} k_{t}^{w}\right)$, and $A_{t}^{s}$ is the adjustment costs of the household, where $A_{t}^{s}=0.5 a^{s, b, e}\left(e_{t}^{\text {bank }}-e_{s s}^{\text {bank }}\right)^{2}+0.5 a^{s, w, e}\left(e_{t}^{w, t o t a l}-e_{s s}^{w, t o t a l}\right)^{2}+0.5 a^{s, d}\left(d_{t}^{h}-d_{s s}^{h}\right)^{2}$ $+0.5 a^{s, b, f}\left(Q_{t} B_{t}^{f}-Q_{s s} B_{s s}^{f s}\right)^{2}+0.5 a^{s, b, g}\left(B_{t}^{g, h}-B_{s s}^{g, h}\right)^{2}$.

\subsection{Firms}

\subsubsection{Wholesale producers}

Wholesale producers in the economy live for two periods. All newly-born firms are identical, but in the second period of their life their TFP is high $\left(\bar{A}_{t}\right)$ or low $\left(\underline{A}_{t}\right)$ with probability $1-\theta_{w}$ and $\theta_{w}$ respectively. Firms receive equity investment from households, issue secured $\left(\mu_{t+1}^{w, s}\right)$ and unsecured $\left(\mu_{t+1}^{w, u}\right)$ debt to banks, and purchase capital $\left(k_{t+1}^{w}\right)$. Each firm decides how much labour $\left(l_{t}^{w}\right)$ it wants to hire on the basis of its productivity. A fraction coll of the expected future value capital is used as collateral for secured debt. Unsecured debt can be renegotiated with creditors, after which firms can obtain a haircut of $\left(\delta_{t}^{w}\right)$, which we call the 'loss given default'.

Production is given by

$$
y_{t}^{j}=A_{t}^{j}\left(k_{t}^{j}\right)^{\alpha}\left(l_{t}^{j}\right)^{1-\alpha}
$$

The first-period real budget constraint of a firm takes the form:

$$
p_{t}^{K} k_{t+1}^{w}+T^{w}+A_{t}^{w} \leq \mu_{t+1}^{w, u}+\mu_{t+1}^{w, s}+e_{t}^{w, t o t a l}
$$

where $A_{t}^{w}$ are the adjustment costs of the firm:

$$
\begin{aligned}
A_{t}^{w}=0.5 a^{w, u}\left(\mu_{t+1}^{w, u}-\mu_{s s}^{w, u}\right)^{2}+0.5 a^{w, s}\left(\mu_{t+1}^{w, s}-\mu_{s s}^{w, s}\right)^{2} & \\
& +0.5 a^{w, k} p_{t}^{K}\left(k_{t+1}^{w}-k_{s s}^{w}\right)^{2} .
\end{aligned}
$$


The collateral constraint is:

$$
\mathbb{E}_{t}\left(1+r_{t+1}^{w, s}\right) \mu_{t+1}^{w, s} \leq \operatorname{coll}(1-\tau) k_{t+1}^{w} \mathbb{E}_{t} p_{t+1}^{K}
$$

In the second period, profit is given by:

$$
\begin{aligned}
\Pi_{t+1}^{w} & =p_{t+1}^{w} A_{t+1}^{w}\left(k_{t+1}^{w}\right)^{\alpha}\left(l_{t+1}^{w}\right)^{1-\alpha} \\
-\left(1-\delta_{t+1}^{w}\right) \mu_{t+1}^{w, u}\left(1+r_{t+1}^{w, u}\right)-\mu_{t+1}^{w, s}\left(1+r_{t+1}^{w, s}\right)-w_{t+1} l_{t+1}^{w} & \quad-\frac{\Omega_{t+1}^{w}}{1+\psi}\left(\delta_{t+1}^{w} \mu_{t+1}^{w, u}\left(1+r_{t+1}^{w, u}\right)\right)^{1+\psi}+p_{t+1}^{K} k_{t+1}^{w}(1-\tau)
\end{aligned}
$$

Thus, depending on its level of technology $\left(\bar{A}_{t}\right.$ or $\left.\underline{A}_{t}\right)$, the firm's profit can either be $\bar{\Pi}_{t}$ or $\underline{\Pi}_{t}{ }^{6}$

$\Omega_{t}{ }^{w}$ is a macro-variable that represents the aggregate credit conditions. ${ }^{7}$ It evolves according to:

$$
\Omega_{t}^{w}=\Omega_{s s}^{w}\left(\frac{\mu_{s s}^{w, u}\left(1+r_{s s}^{w, u}\right)}{G D P_{s s}}\right)^{\omega}\left(\delta_{s s}^{w}\right)^{\gamma}\left(\frac{G D P_{t}}{\mu_{t}^{w, u}\left(1+r_{t}^{w, u}\right)}\right)^{\omega} \frac{1}{\left(\delta_{t}^{w}\right)^{\gamma}}
$$

The wholesale producer solves:

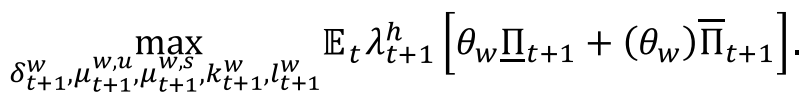

\subsubsection{Intermediate goods producers}

Intermediate goods producers are monopolistically competitive and produce a differentiated intermediate good using wholesale goods:

$$
Y_{t}^{r e t}(k)=Y_{t}^{w}(k)
$$

They therefore solve:

$$
\min _{Y_{t}^{r e t}(k)} \frac{P_{t}^{w}}{P_{t}} Y_{t}^{r e t}(k)+\lambda_{t}^{r e t}\left(Y_{t}^{r e t}(k)-Y_{t}^{w}(k)\right)
$$

Price stickiness is introduced into the model in a standard New Keynesian manner, following Brzoza-Brzezina et al. (2013). The intermediate goods producer sets the price $p_{t}(k)$ by solving:

\footnotetext{
${ }^{6}$ We assume that renegotiation only occurs when productivity has been low. If productivity is high, the haircut is zero and there is no cost of renegotiation in (6).

${ }^{7}$ As $\Omega$ is a macro-variable which firms take as given, there is a direct externality arising from the renegotiation of unsecured debt. The cost of renegotiating debt effectively creates a borrowing constraint, as discussed in Shubik and Wilson (1977) and Dubey et al. (2005) and as applied in Tsomocos (2003), Goodhart et al. (2005) and Goodhart et al. (2006).
} 


$$
\begin{aligned}
\max _{p_{t}(k)} \lambda_{t}^{h}\left[\frac{p_{t}(k)}{P_{t}}\right. & \left.c_{t}(k)-\lambda_{t}^{r e t} c_{t}(k)\right] \\
& +\mathbb{E}_{t} \sum_{i=1}^{\infty}\left(\beta_{t}^{h} \theta_{p s}\right)^{i} \lambda_{t+i}^{h}\left[\frac{p_{t}(k)}{P_{t+i}} c_{t+i}(k)-\lambda_{t+i}^{r e t} c_{t+i}(k)\right]
\end{aligned}
$$

subject to $Y_{t}^{r e t}(k)=\left(\frac{p_{t}(k)}{P_{t}}\right)^{-\theta_{c}} Y_{t}^{\text {ret }}$.

\subsubsection{Domestically-priced final goods producers (retailers)}

Domestically-priced final goods producers create a composite final good using as input goods purchased from intermediate goods producers. The good is then demanded by households and the government, and is given by:

$$
Y_{t}^{r e t}=\left(\int_{0}^{1} Y_{t}^{r e t}(k)^{\left(\theta_{c}-1\right) / \theta_{c}} d k\right)^{\frac{\theta_{c}}{\left(\theta_{c}-1\right)}} .
$$

\subsubsection{Capital producers}

Capital producers purchase imported goods $i_{T, t}$ at price $p_{t}^{i m p}$ and domestic goods $i_{N, t}$ to produce aggregate investment goods $i_{t}$ in accordance with their technology, represented by a constant elasticity of substitution (CES) aggregator:

$$
i_{t}=A^{i}\left[\left(\phi^{i}\right)^{\frac{1}{v_{i}}} i_{N, t}^{\frac{v_{i}-1}{v_{i}}}+\left(1-\phi^{i}\right)^{\frac{1}{v_{i}}} i_{T, t}^{\frac{v_{i}-1}{v_{i}}}\right]^{\frac{v_{i}}{v_{i}-1}} .
$$

The capital production technology implies an adjustment cost. The production function takes the form:

$$
K_{t}=(1-\tau) K_{t-1}+i_{t}\left(1-\frac{\varkappa}{2}\left(\frac{i_{t}}{i_{t-1}}-1\right)^{2}\right) .
$$

Capital producers sell new capital to wholesale producers. The profit is:

$$
\Pi_{t}^{c a p}=p_{t}^{K} i_{t}\left(1-\frac{\varkappa}{2}\left(\frac{i_{t}}{i_{t-1}}-1\right)^{2}\right)-i_{N, t}-i_{T, t} p_{t}^{i m p}
$$

Capital producers solve:

$$
\max _{i_{t}} E_{0} \sum_{t=1}^{\infty}\left(\beta_{t-1}^{h}\right)^{t} \lambda_{t}^{h} \Pi_{t}^{c a p}
$$

\subsection{Banking sector}

Banks live for two periods. New-born banks are capitalized with equity $\left(e_{t}^{\text {bank }}\right)$. They accept deposits from households $\left(d_{t+1}^{\text {bank }}\right)$ and extend secured $\left(\mu_{t+1}^{\text {bank,s }}\right)$ and unsecured $\left(\mu_{t+1}^{\text {bank,u}}\right)$ loans to firms. Given $\left\{\delta_{t+1}^{w}, r_{t+1}^{w, u}, r_{t+1}^{w, s}, r_{t+1}^{d}\right\}$, banks maximize: 
$\max _{t+1}^{\text {bank,u}, \mu_{t+1}^{\text {bank,s }}, d_{t+1}^{\text {bank }}} \mathbb{E}_{t} \beta_{t}^{h} \frac{\left(\Pi_{t+1}^{\text {bank }}\right)^{1-\varsigma_{\text {bank }}}}{1-\varsigma_{\text {bank }}}-a_{c a p} 0.5\left[k_{t}^{\text {bank }}-\bar{k}^{\text {bank }}\right]^{2}$,

where $k_{t}^{\text {bank }}$ is the capital adequacy ratio, defined as the ratio of bank capital to risk-weighted assets net of reserves $\left(r w a_{t}^{\text {bank }}\right)$ :

$$
k_{t}^{\text {bank }}=\frac{e_{t}^{\text {bank }}}{r w a_{t}^{\text {bank }}}=\frac{e_{t}^{\text {bank }}}{\left(\overline{r w} \mu_{t+1}^{\text {bank,u}}+\overline{r w} \mu_{t+1}^{\text {bank,s}}\right)^{-}} .
$$

Here, for simplicity, we assume the same risk weights for secured and unsecured lending.

The first-period budget constraint of a bank is given by

$$
\mu_{t+1}^{\text {bank }}=d_{t+1}^{\text {bank }}+e_{t}^{\text {bank }}-A_{t}^{\text {bank }}
$$

where $\mu_{t+1}^{\text {bank }}=\mu_{t+1}^{\text {bank,s }}+\mu_{t+1}^{\text {bank, } u}$, and $A_{t}^{\text {bank }}$ are the adjustment costs for the bank, where $A_{t}^{\text {bank }}=0.5 a^{b, s}\left(\mu_{t+1}^{\text {bank,s }}-\mu_{s s}^{\text {bank,s }}\right)^{2}+0.5 a^{b, u}\left(\mu_{t+1}^{\text {bank,u }}-\mu_{s s}^{\text {bank,u }}\right)^{2}$ $+0.5 a^{b, d}\left(d_{t+1}^{\text {bank }}-d_{s s}^{\text {bank }}\right)^{2}$.

Profits in the second period of operations are given by

$$
\begin{array}{r}
\Pi_{t+1}^{\text {bank }}=\theta^{w}\left(1+r_{t+1}^{w, u}\right)\left(1-\delta_{t+1}^{w}\right) \mu_{t+1}^{\text {bank,u}}+\left(1-\theta^{w}\right)\left(1+r_{t+1}^{w, u}\right) \mu_{t+1}^{\text {bank,u }} \\
+\left(1+r_{t+1}^{w, s}\right) \mu_{t+1}^{\text {bank, } s}-\left(1+r_{t+1}^{d}\right) d_{t+1}^{\text {bank }}
\end{array}
$$

where $r_{t}^{w, u}$ and $r_{t}^{w, s}$ are unsecured and secured lending rates, respectively.

\subsection{Government}

\subsubsection{Fiscal authority}

The government receives all the revenue $\left(p_{t}^{o, d o m} O_{t}\right)$ from oil export $O_{t}$. The government spends its funds on domestically produced final goods $\left(G_{t}\right)$ and imported goods $\left(G_{t}^{i m p}\right)$, can save or borrow through domestic government bonds $\left(B_{t}^{g}\right)$, and receives constant net taxes from agents in the economy.

The government budget constraint is:

$$
G_{t}+p_{t}^{i m p} G_{t}^{i m p}+B_{t-1}^{g} \frac{\left(1+i_{t-1}^{b}\right)}{1+\pi_{t}}=B_{t}^{g}+p_{t}^{o, d o m} O_{t}+T^{w}
$$

\subsubsection{Monetary authority}

The Central Bank controls the interest rate $i_{t}^{b}$ according to the following rule:

$$
\frac{1+i_{t}^{b}}{1+i_{S S}^{b}}=\left(\frac{1+i_{t-1}^{b}}{1+i_{s S}^{b}}\right)^{\rho_{i}}\left(\frac{1+\pi_{t}^{c p i}}{1+\pi_{s S}^{c p i}}\right)^{1+\rho_{\pi}}\left(\frac{G D P_{t}}{G D P_{S S}}\right)^{\rho_{g d p}} \varepsilon_{t}^{i}
$$

where $\varepsilon_{t}^{R}$ is a monetary policy shock that follows an $\operatorname{AR}(1)$ process. 
For macroprudential policy analysis, the Taylor rule is augmented by a component representing the ratio of current unsecured lending to its steady state level. This would result in a higher policy rate when there is excessive unsecured lending in the economy.

The Taylor rule applied is the adjusted multiplicative form of the linear Taylor rule proposed in Taylor (1993). It is similar to the rule used in BrzozaBrzezina et al. (2013) and consistent with other DSGE models (Adolfson et al., 2013; Christiano et al., 2015).

\subsubsection{Macroprudential policy tools}

The monetary authority is responsible for monetary and macroprudential regulation. Macroprudential regulation can be implemented through several channels. Firstly, the monetary authority can change the capital adequacy requirements imposed on banks. This includes setting the risk weights of different types of assets. Secondly, when setting the nominal interest rate, the monetary authority can follow a LAW-type Taylor rule, accounting for the growth of credit in the economy. Thirdly, deposit requirements can be set to regulate the credit cycle. Finally, the monetary authority can regulate the demand for loans through the LTV ratio. We focus on policies that take the level of unsecured debt as a target, as this was found to result in a larger effect than considering policies that targeted the level of total or unsecured debt.

The LAW rule is a modified Taylor rule represented by the equation

$$
\frac{1+i_{t}^{b}}{1+i_{s s}^{b}}=\left(\frac{1+i_{t-1}^{b}}{1+i_{s s}^{b}}\right)^{\rho_{i}}\left(\frac{1+\pi_{t}^{c p i}}{1+\pi_{s s}^{c p i}}\right)^{1+\rho_{\pi}}\left(\frac{G D P_{t}}{G D P_{s s}}\right)^{\rho_{g d p}}\left(\frac{\mu_{t+1}^{\text {bank,u}}}{\mu_{s s}^{b a n k, u}}\right)^{S} \varepsilon_{t}^{i}
$$

In this type of Taylor rule, the policy rate not only depends on the policy rate for the previous period, current CPI inflation, and GDP, but also reacts positively to the growth of unsecured debt in the economy. We set $\varsigma=0.5$ for our policy analysis.

A policy rule for deposit requirements suggests the existence of a deposit reserve ratio. In accordance with this rule, all banks transfer a share res $t$ of deposits to the budget each period and receive the same nominal amount next period. The dynamics of res $_{t}$ are captured by the equation:

$$
\operatorname{res}_{t}=\left(\frac{\mu_{t+1}^{\text {bank,u}}}{\mu_{s s}^{\text {bank,u}}}\right)^{v}-1
$$

The deposit reserve ratio is often considered as a tool for regulating liquidity, which is not usually represented in models. However, the deposit reserve ratio also affects banks' internal return on funding and the attractiveness of investing in the banking sector. The deposit reserve ratio therefore affects financial sector 
variables and can be considered a macroprudential tool. We set $v=0.015$ for our policy analysis.

The LTV macroprudential policy rule suggests the collateral discount coll (equation (5)) should be dynamic and regulates it in accordance with the law:

$$
\operatorname{coll}_{t}=\operatorname{coll}_{s s}\left(\frac{\mu_{t+1}^{\text {bank, } u}}{\mu_{s s}^{\text {bank,u}}}\right)^{\chi} .
$$

When aggregate unsecured loans exceed the steady state, the amount of capital that is collateralized increases. As a result, firms are forced to finance a larger proportion of their expenditure on capital through secured debt. Firms then need to reduce the loan to (expected) value ratio of undepreciated capital. This changes the internal cost of collateral constraint and the demand for loans. We set $\chi=-0.5$ for our policy analysis.

The capital adequacy rule concerns the capital adequacy ratio $\bar{k}^{\text {bank }}$, a dynamic variable, and regulates it based on the equation

$$
\bar{k}_{t}^{\text {bank }}=\bar{k}_{s s}^{\text {bank }}\left(\frac{\mu_{t+1}^{\text {bank,u}}}{\mu_{s s}^{\text {bank,u}}}\right)^{\eta} .
$$

Higher aggregate unsecured loans lead to higher capital adequacy requirements. This rule affects the internal profitability of lending and the supply of loans. We set $\eta=0.5$ for our policy analysis.

\subsection{Markets and prices}

We use the standard definition of equilibrium for a competitive dynamic economy. Given exogenous shocks, equilibrium is a sequence of prices and quantities such that each agent in the economy maximizes his or her value and all markets clear. In particular, the market clearing condition for labour requires:

secured loans:

$$
l_{t}^{h}=l_{t}^{w},
$$

$$
\mu_{t}^{\text {bank,s}}=\mu_{t}^{w, s},
$$

unsecured loans:

$$
\mu_{t}^{\text {bank, } u}=\mu_{t}^{w, u}
$$

deposits:

$$
d_{t}^{h}=d_{t}^{\text {bank }},
$$

domestic bonds:

$$
B_{t}^{g}=B_{t}^{g, h},
$$


domestic output:

$$
\begin{aligned}
Y_{t}^{r e t}=c_{t}^{N}+i_{t}^{N}+G_{t}+\theta^{w} \frac{\Omega_{t}^{w}}{1+\psi}\left(\delta_{t}^{w} \mu_{t}^{w}\left(1+r_{t}^{w, u}\right)\right)^{1+\psi} & \\
& +A_{t}^{s}+A_{t}^{w}+A_{t}^{\text {bank }}
\end{aligned}
$$

The household time-preference variable $\beta_{t}^{h}$ is defined as the product of the time-preference parameter and time-preference shock:

$$
\beta_{t}^{h}=\beta^{h} \varepsilon_{t}^{\beta, h}
$$

The domestic price of an imported good is:

$$
p_{t}^{i m p}=Q_{t} p^{i m p, \star}
$$

where $p^{i m p, *}$ is the international price of an imported good, assumed to be constant, and $Q_{t}$ is the real exchange rate.

The domestic price of a commodity good (oil) is:

$$
p_{t}^{o, d o m}=Q_{t} p_{t}^{o, \star}
$$

where $p_{t}^{o, *}$ is the international price of the commodity good, defined as:

$$
p_{t}^{o, \star}=p^{o, \star} \varepsilon_{t}^{p, o}
$$

Thus, the international price of oil is a product of some constant oil price $p^{0, *}$ and its shock process $\varepsilon_{t}^{p, o}$, which follows an $\operatorname{AR}(1)$ process.

The interest rate on foreign bonds is also subject to the shock, which we call the 'foreign interest rate shock. The interest rate on foreign bonds is therefore defined as:

$$
r_{t}^{f}=r^{f}+\varepsilon_{t}^{i, f o r}
$$

where $r^{f}$ is some constant interest rate on foreign bonds and $\varepsilon_{t}^{i, f o r}$ is a shock process for the interest rate on foreign bonds, which follows an $\mathrm{AR}(1)$ process.

The technology levels of 'lucky' and 'unlucky' firms are $\bar{A}_{t}^{j}$ and $\underline{A}_{t}^{j}$ respectively:

$$
\bar{A}_{t}^{j}=A_{t} \bar{A}^{j}
$$

where $\bar{A}^{j}$ is some constant and

$$
\underline{A}_{t}^{j}=A_{t} \underline{A}^{j}
$$

where $\underline{A}^{j}$ is some constant with $\bar{A}^{j}>1>\underline{A}^{j}$. 
The real interest rate on domestic government bonds is defined as:

$$
1+r_{t}^{b}=\frac{1+i_{t-1}^{b}}{1+\pi_{t}}
$$

\section{Simulation}

In this section, we simulate our model economy and conduct normative monetary and macroprudential policy analysis. We approximate our model economy by taking a first-order Taylor approximation around a deterministic steady state.

\subsection{Calibrated parameters and steady state}

The parameter values we use are largely taken from the estimation in Andreev et al. (2019) based on quarterly Russian data from 2001Q2 to 2018Q2 for GDP, consumption, the dollar oil price, real loans, real deposits, non-performing loans (NPLs), CPI inflation, and the one-day interbank interest rate.

Parameter values are given in Tables 1 and 2. In its steady state, the household time-preference parameter $\beta$ is set to yield an annual risk-free rate of about 9.4\%, which corresponds to the average Russian government bond yield for the period we consider. The loss given default value $\delta f$ is also set in accordance with the Russian data. The capital requirement for banks $k^{\text {bank }}$ corresponds to the Russian capital requirement for systemically important banks. The depreciation rate $\tau$ is set to yield an annual depreciation rate of $10 \%$. The fraction of firms that default, $\theta_{f}$, is calibrated to Russian banks' statistics on defaults by firms. We also calibrated the steady state size of the oil sector in the economy to a GDP of about $26 \%$, which is in line with the Russian statistics in our sample period.

The parameter values that we use for our calibration are close to those used or estimated in other models of the Russian economy. For instance, the depreciation rate corresponds to the rate used in Malakhovskaya and Minabutdinov (2014). As follows from Malakhovskaya and Minabutdinov (2014), the estimated value of household risk aversion for the Russian economy is 1.015. In Polbin (2014) the estimated mean value of household risk aversion is close to its prior value of 1.19 .

The steady state values of the variables are presented in Table 3.

\subsection{Business cycle statistics}

The business cycle statistics given by the model are represented in Table 4 . By comparing the business cycle statistics simulated by the model with the data, we can see that the model does a good job of capturing the volatility of most of the variables; however, it overestimates the volatility of consumption growth and GDP growth by almost a factor of two. 
Table 1. Calibrated parameters and ratios

\begin{tabular}{|c|c|c|c|}
\hline Parameters & Value & Description & Source \\
\hline$A^{c}$ & 2.9 & Consumption aggregator scale & Andreev et al. (2019) \\
\hline$A^{i}$ & 0.8 & Capital production technology & Andreev et al. (2019) \\
\hline$\beta^{h}$ & 0.977 & Household's time preference & Calibrated to data \\
\hline$\theta^{h}$ & 1 & Household's disutility from labour & Andreev et al. (2019) \\
\hline$\gamma^{h}$ & 1 & Household's labour elasticity & Christiano et al. (2010) \\
\hline$\sigma^{h}$ & 1.5 & Household's risk aversion & Andreev et al. (2019) \\
\hline$\phi^{h}$ & 0.65 & $\begin{array}{l}\text { Household's preference for domestic } \\
\text { goods }\end{array}$ & Kreptsev and Seleznev (2017) \\
\hline$v^{c}$ & 0.94 & $\begin{array}{l}\text { Elasticity of substitution between } \\
\text { domestic and foreign consumption goods }\end{array}$ & Kreptsev and Seleznev (2017) \\
\hline$\phi^{i}$ & 0.5 & Share of domestic goods in investment & Andreev et al. (2019) \\
\hline$v^{i}$ & 0.98 & $\begin{array}{l}\text { Elasticity of substitution between } \\
\text { domestic and foreign investment goods }\end{array}$ & Kreptsev and Seleznev (2017) \\
\hline$\varsigma_{\text {bank }}$ & 1 & Bank's risk aversion & Andreev et al. (2019) \\
\hline$\beta^{\text {bank }}$ & 0.977 & Bank's time preference & Calibrated to data \\
\hline$\delta^{f}$ & 0.5 & Loss given default & Calibrated to data \\
\hline$k^{\text {bank }}$ & 0.115 & Capital requirements for banks & Calibrated to data \\
\hline$\overline{r w}$ & 1 & Bank's risk-weight & Calibrated to data \\
\hline$\tau$ & 0.025 & Depreciation rate & Polbin (2014) \\
\hline$\alpha$ & 0.33 & Capital share in wholesaler's production & $\begin{array}{l}\text { Malakhovskaya and } \\
\text { Minabutdinov (2014) }\end{array}$ \\
\hline coll & 0.65 & Collateral value of capital & Calibrated to data \\
\hline$\theta_{f}$ & 0.05 & Fraction of firms defaulting & Calibrated to data \\
\hline$\theta^{c}$ & 3 & Elasticity of retailer's output & Andreev et al. (2019) \\
\hline$\epsilon_{w}$ & 4 & Elasticity of labour demand & Andreev et al. (2019) \\
\hline$a^{s, d}$ & 0.052 & Household's adjustment cost to deposits & Andreev et al. (2019) \\
\hline$a^{s, b, f}$ & 0.029 & $\begin{array}{l}\text { Household's adjustment cost to foreign } \\
\text { bonds }\end{array}$ & Andreev et al. (2019) \\
\hline$a^{s, b, g}$ & 0.010 & $\begin{array}{l}\text { Household's adjustment cost to domestic } \\
\text { bonds }\end{array}$ & Andreev et al. (2019) \\
\hline$a^{s, b, e}$ & 0.052 & $\begin{array}{l}\text { Household's adjustment cost to bank's } \\
\text { equity }\end{array}$ & Andreev et al. (2019) \\
\hline$a^{s, f, e}$ & 0.032 & $\begin{array}{l}\text { Household's adjustment cost to firm's } \\
\text { equity }\end{array}$ & Andreev et al. (2019) \\
\hline$a^{w, k}$ & 0.060 & Firm's adjustment cost to capital & Andreev et al. (2019) \\
\hline$a^{w, s}$ & 0.005 & Firm's adjustment cost to secured loans & Andreev et al. (2019) \\
\hline$a^{w, u}$ & 0.006 & Firm's adjustment cost to unsecured loans & Andreev et al. (2019) \\
\hline$a^{b, d}$ & 0.005 & Bank's adjustment cost to deposits & Andreev et al. (2019) \\
\hline$a^{b, s}$ & 0.021 & Bank's adjustment cost to secured loans & Andreev et al. (2019) \\
\hline$a^{b, u}$ & 0.005 & Bank's adjustment cost to unsecured loans & Andreev et al. (2019) \\
\hline$\varkappa$ & 0.098 & $\begin{array}{l}\text { Capital producer's adjustment cost } \\
\text { to investment }\end{array}$ & Andreev et al. (2019) \\
\hline$\theta^{p, w}$ & 0.046 & Wage stickiness & Andreev et al. (2019) \\
\hline$\theta^{p, s}$ & 0.408 & Price stickiness & Andreev et al. (2019) \\
\hline
\end{tabular}


Continuation, Table 1 begins on p. 16

\begin{tabular}{llll} 
Parameters & Value & Description & Source \\
\hline$\rho^{i}$ & 0.901 & Interest rate coefficient & Andreev et al. (2019) \\
\hline$\rho^{\pi}$ & 1.170 & Inflation rate coefficient & Andreev et al. (2019) \\
\hline$\rho^{g d p}$ & 0.291 & GDP growth rate coefficient & Andreev et al. (2019) \\
\hline$\gamma$ & 1.540 & Default amplification in $\Omega$ & Andreev et al. (2019) \\
\hline$\omega$ & 0.682 & Credit to GDP amplification in $\Omega$ & Andreev et al. (2019) \\
\hline$\psi$ & 1.998 & Default cost & Andreev et al. (2019) \\
\hline$\rho^{p, o}$ & 0.937 & Persistence of oil price shock & Andreev et al. (2019) \\
\hline$\rho^{a}$ & 0.910 & Persistence of TFP shock & Andreev et al. (2019) \\
\hline$\rho^{\text {mon }}$ & 0.062 & Persistence of monetary policy shock & Andreev et al. (2019) \\
\hline$\rho^{i, f o r}$ & 0.902 & Persistence of foreign interest rate shock & Andreev et al. (2019) \\
\hline$\rho^{\beta, h}$ & 0.099 & $\begin{array}{l}\text { Persistence of household s time- } \\
\text { preference shock }\end{array}$ & Andreev et al. (2019) \\
\hline Calibrated ratios & & & Calibrated to data \\
\hline Oil export/ GDP & 0.26 & Oil export to GDP & \\
\hline & & & \\
\hline
\end{tabular}

Table 2. Shocks applied

\begin{tabular}{llll} 
Shocks & Value & Description & Source \\
\hline$\epsilon^{p, o}$ & 0.135 & Standard deviation of oil price shock & Andreev et al. (2019) \\
\hline$\epsilon^{a}$ & 0.035 & Standard deviation of TFP shock & Andreev et al. (2019) \\
\hline$\epsilon^{\text {mon }}$ & 0.019 & Standard deviation of monetary policy shock & Andreev et al. (2019) \\
\hline$\epsilon^{i, f o r}$ & 0.008 & $\begin{array}{l}\text { Standard deviation of foreign interest rate } \\
\text { shock }\end{array}$ & Andreev et al. (2019) \\
\hline$\epsilon^{\beta, h}$ & 0.029 & $\begin{array}{l}\text { Standard deviation of household's time- } \\
\text { preference shock }\end{array}$ & Andreev et al. (2019) \\
\hline
\end{tabular}

Table 3. Steady state values of variables

\begin{tabular}{lll} 
Variable & Variable name & Value \\
\hline $\bar{A}$ & Lucky wholesale producer's technology level & 2.000 \\
\hline$\underline{A}$ & Unlucky wholesale producer's technology level & 0.500 \\
\hline$B^{f}$ & Household holdings of foreign bonds & 0 \\
\hline$B^{g, h}$ & Household holdings of domestic bonds & 0 \\
\hline$B^{g}$ & Domestic government bond & 0 \\
\hline$c_{N}$ & Household consumption of domestic goods & 1.240 \\
\hline$C_{T}$ & Household consumption of imported goods & 1.237 \\
\hline$d^{\text {bank }}$ & Bank's deposits & 5.307 \\
\hline$d^{h}$ & Household's deposits & 5.307 \\
\hline$\delta^{w}$ & Loss given default rate & 0.5 \\
\hline$e^{\text {bank }}$ & Bank's equity & 0.690 \\
\hline$e^{w, t o t a l}$ & Wholesale producer's total equity & 2.308 \\
\hline$G$ & Government spending on final domestic goods & 0.817
\end{tabular}


Continuation, Table 3 begins on p. 17

\begin{tabular}{|c|c|c|}
\hline Variable & Variable name & Value \\
\hline$G^{i m p}$ & Government spending on imported goods & 0.066 \\
\hline$r^{b}$ & Real interest rate on domestic government bonds & 0.024 \\
\hline$r^{d}$ & Real interest rate on deposits & 0.024 \\
\hline$r^{w, u}$ & Real interest rate on unsecured loans to firms & 0.050 \\
\hline$r^{w, s}$ & Real interest rate on secured loans to firms & 0.024 \\
\hline$i^{b}$ & Policy rate & 0.024 \\
\hline$i_{N}$ & Domestic investment goods & 0.104 \\
\hline$i_{T}$ & Imported investment goods & 0.197 \\
\hline$K$ & Capital stock & 9.133 \\
\hline$l^{h}$ & Labour supplied by household & 0.383 \\
\hline$l^{w}$ & Labour demanded by wholesale producer & 0.383 \\
\hline$\mu^{\text {bank }}$ & Total lending by bank & 5.997 \\
\hline$\mu^{\text {bank,s }}$ & Secured lending by bank & 5.097 \\
\hline$\mu^{\text {bank,u}}$ & Unsecured lending by bank & 0.900 \\
\hline$\mu^{w}$ & Total borrowing by wholesale producer & 5.997 \\
\hline$\mu^{w, s}$ & Secured borrowing by wholesale producer & 5.097 \\
\hline$\mu^{w, u}$ & Unsecured borrowing by wholesale producer & 0.900 \\
\hline 0 & Oil export & 1.500 \\
\hline$p^{e x p, *}$ & International price of exported good & 1 \\
\hline$p^{i m p, *}$ & International price of imported good & 1 \\
\hline$p^{e x p}$ & Domestic price of exported good & 0.519 \\
\hline$p^{i m p}$ & Domestic price of imported good & 0.519 \\
\hline$p^{K}$ & Price of capital & 0.901 \\
\hline$p^{o, *}$ & International price of oil & 1 \\
\hline$p^{o, d o m}$ & Domestic price of oil & 0.519 \\
\hline$p^{w}$ & Price of wholesale good & 0.667 \\
\hline$\pi$ & Inflation rate & 0 \\
\hline$\Pi$ & Bank's profit & 0.706 \\
\hline$\Pi^{r e t}$ & Retailer's profit & 0.723 \\
\hline $\bar{\Pi}^{w}$ & Lucky wholesale producer's profit & 2.372 \\
\hline$\Pi^{w}$ & Unlucky wholesale producer's profit & 2.188 \\
\hline$Q$ & Real exchange rate & 0.519 \\
\hline$T^{w}$ & Firm's lump-sum tax & 0.073 \\
\hline$v^{p}$ & Price persistence & 1 \\
\hline$w$ & Wage rate & 2.516 \\
\hline$Y^{\text {ret }}$ & Retailer's output & 2.168 \\
\hline
\end{tabular}

Certain of the correlations in the data tally with the corresponding model variables. In particular, the model does a good job of capturing the size of the correlation between GDP growth and oil price growth, although it slightly overestimates the correlation between GDP growth and consumption growth. 
The correlation of GDP growth with loans and deposit growth is highly underestimated. The model also implies the wrong correlation between NPLs and GDP growth, as well as between NPLs and oil price growth. The model correctly captures the correlations between the interest rate and loan growth, deposit growth, and CPI inflation; however, the correlation between the interest rate and NPLs is significantly overestimated.

The corresponding business cycle statistics for the Russian economy for the period 2001Q2-2018Q2 are given in Table 5.

Table 4. Model business cycle statistics

\begin{tabular}{|c|c|c|c|c|c|c|c|c|}
\hline & $\begin{array}{c}\text { GDP, } \\
\text { q/q } \\
\text { growth, \% }\end{array}$ & $\begin{array}{l}\text { Consumption, } \\
\text { q/q growth, \% }\end{array}$ & $\begin{array}{c}\text { Oil price, } \\
\text { q/q } \\
\text { growth, } \%\end{array}$ & $\begin{array}{c}\text { Real } \\
\text { loans, } \\
\text { q/q } \\
\text { growth, \% }\end{array}$ & $\begin{array}{c}\text { Real } \\
\text { deposits, } \\
\text { q/q } \\
\text { growth, \% }\end{array}$ & $\begin{array}{c}\text { NPL to } \\
\text { loans, } \\
\text { quarterly, } \\
\%\end{array}$ & $\begin{array}{c}\text { CPI, } \\
\text { quarterly, } \\
\%\end{array}$ & $\begin{array}{c}\text { Interest } \\
\text { rate, } \\
\text { quarterly, } \\
\%\end{array}$ \\
\hline $\begin{array}{l}\text { Standard } \\
\text { deviation }\end{array}$ & 2.91 & 3.52 & 14.49 & 4.37 & 5.46 & 1.74 & 1.34 & 1.60 \\
\hline \multicolumn{9}{|l|}{ Correlation } \\
\hline $\begin{array}{l}\text { GDP, q/q } \\
\text { growth, \% }\end{array}$ & 1 & 0.81 & 0.46 & 0.23 & 0.11 & 0.13 & -0.33 & -0.20 \\
\hline $\begin{array}{l}\text { Consumption, } \\
\text { q/q growth, \% }\end{array}$ & 0.81 & 1 & 0.17 & 0.20 & -0.02 & 0.07 & -0.20 & -0.10 \\
\hline $\begin{array}{l}\text { Oil price, q/q } \\
\text { growth, } \%\end{array}$ & 0.46 & 0.17 & 1 & 0.06 & 0.76 & 0.14 & -0.35 & -0.30 \\
\hline $\begin{array}{l}\text { Real loans, } \\
\text { q/q growth, \% }\end{array}$ & 0.23 & 0.20 & 0.06 & 1 & 0.24 & 0.02 & -0.27 & -0.44 \\
\hline $\begin{array}{l}\text { Real deposits, } \\
\text { q/q growth, \% }\end{array}$ & 0.11 & -0.02 & 0.76 & 0.24 & 1 & 0.12 & -0.29 & -0.35 \\
\hline $\begin{array}{l}\text { NPL to loans, } \\
\text { quarterly, \% }\end{array}$ & 0.13 & 0.07 & 0.14 & 0.02 & 0.12 & 1 & 0.01 & 0.68 \\
\hline $\begin{array}{l}\text { CPI, } \\
\text { quarterly, \% }\end{array}$ & -0.33 & -0.20 & -0.35 & -0.27 & -0.29 & 0.01 & 1 & 0.46 \\
\hline $\begin{array}{l}\text { Interest rate, } \\
\text { quarterly, \% }\end{array}$ & -0.20 & -0.10 & -0.30 & -0.44 & -0.35 & 0.68 & 0.46 & 1 \\
\hline
\end{tabular}

Note: q/q - quarter-on-quarter.

Table 5. Selected business cycle statistics 2001Q2-2018Q2

\begin{tabular}{|c|c|c|c|c|c|c|c|c|}
\hline & $\begin{array}{c}\text { GDP, } \\
\text { q/q } \\
\text { growth, \% }\end{array}$ & $\begin{array}{l}\text { Consumption, } \\
\text { q/q growth, \% }\end{array}$ & $\begin{array}{l}\text { Oil price, } \\
\text { q/q } \\
\text { growth, } \%\end{array}$ & $\begin{array}{c}\text { Real } \\
\text { loans, } \\
\text { q/q } \\
\text { growth, \% }\end{array}$ & $\begin{array}{c}\text { Real } \\
\text { deposits, } \\
\text { q/q } \\
\text { growth, \% }\end{array}$ & $\begin{array}{l}\text { NPL to } \\
\text { loans, } \\
\text { quarterly, } \\
\%\end{array}$ & $\begin{array}{c}\text { CPI, } \\
\text { quarterly, } \\
\%\end{array}$ & $\begin{array}{c}\text { Interest } \\
\text { rate, } \\
\text { quarterly, } \\
\%\end{array}$ \\
\hline Mean & 0.82 & 1.32 & 1.99 & 3.19 & 3.97 & 4.35 & 2.33 & 2.21 \\
\hline $\begin{array}{l}\text { Standard } \\
\text { deviation }\end{array}$ & 1.46 & 2.09 & 13.45 & 4.01 & 4.87 & 2.68 & 1.22 & 0.95 \\
\hline \multicolumn{9}{|l|}{ Correlation } \\
\hline $\begin{array}{l}\text { GDP, q/q } \\
\text { growth, \% }\end{array}$ & 1 & 0.66 & 0.47 & 0.61 & 0.7 & -0.34 & -0.06 & -0.53 \\
\hline $\begin{array}{l}\text { Consumption, } \\
\text { q/q growth, \% }\end{array}$ & 0.66 & 1 & 0.36 & 0.66 & 0.47 & -0.49 & -0.14 & -0.45 \\
\hline
\end{tabular}


Continuation, Table 5 begins on p. 19

\begin{tabular}{|c|c|c|c|c|c|c|c|c|}
\hline & $\begin{array}{c}\text { GDP, } \\
\text { q/q } \\
\text { growth, \% }\end{array}$ & $\begin{array}{l}\text { Consumption, } \\
\text { q/q growth, \% }\end{array}$ & $\begin{array}{l}\text { Oil price, } \\
\text { q/q } \\
\text { growth, } \%\end{array}$ & $\begin{array}{c}\begin{array}{c}\text { Real } \\
\text { loans, }\end{array} \\
\text { q/q } \\
\text { growth, \% }\end{array}$ & $\begin{array}{c}\text { Real } \\
\text { deposits, } \\
\text { q/q } \\
\text { growth, \% }\end{array}$ & $\begin{array}{c}\text { NPL to } \\
\text { loans, } \\
\text { quarterly, } \\
\%\end{array}$ & $\begin{array}{c}\text { CPI, } \\
\text { quarterly, } \\
\%\end{array}$ & $\begin{array}{c}\text { Interest } \\
\text { rate, } \\
\text { quarterly, } \\
\%\end{array}$ \\
\hline $\begin{array}{l}\text { Oil price, q/q } \\
\text { growth, } \%\end{array}$ & 0.47 & 0.36 & 1 & 0.16 & 0.45 & -0.05 & -0.20 & -0.41 \\
\hline $\begin{array}{l}\text { Real loans, } \\
\text { q/q growth, \% }\end{array}$ & 0.61 & 0.66 & 0.16 & 1 & 0.51 & -0.69 & 0.09 & -0.42 \\
\hline $\begin{array}{l}\text { Real deposits, } \\
\text { q/q growth, \% }\end{array}$ & 0.7 & 0.47 & 0.45 & 0.51 & 1 & -0.27 & -0.13 & -0.51 \\
\hline $\begin{array}{l}\text { NPL to loans, } \\
\text { quarterly, \% }\end{array}$ & -0.34 & -0.49 & -0.05 & -0.69 & -0.27 & 1 & -0.55 & 0.14 \\
\hline $\begin{array}{l}\text { CPI, } \\
\text { quarterly, \% }\end{array}$ & -0.06 & -0.14 & -0.20 & 0.09 & -0.13 & -0.55 & 1 & 0.37 \\
\hline $\begin{array}{l}\text { Interest rate, } \\
\text { quarterly, \% }\end{array}$ & -0.53 & -0.45 & -0.41 & -0.42 & -0.51 & 0.14 & 0.37 & 1 \\
\hline
\end{tabular}

Note: q/q - quarter-on-quarter.

\subsection{Impulse response functions}

Figure 2 (see p. 25) gives the impulse response functions (IRFs) to a positive one-standard-deviation foreign oil price and TFP shock. ${ }^{8}$ The CPI, domestic price growth rate, and interest rates are given in absolute deviation from the steady state as a percentage change per quarter. The NPL-to-loans ratio and foreign bonds (households' foreign debt) are given in absolute deviation multiplied by 100. All other variables are presented in percentage deviations from the steady state value. ${ }^{9}$

\subsubsection{TFP shock}

A positive TFP shock increases the marginal profitability of production. Firms increase their demand for the factors of production, resulting in an increase in real wages, capital and the price of the capital, and production. As the relative price of capital shifts upwards, the collateral constraint is relaxed and the quantity of secured debt issued increases immediately. As the price of capital falls back to its steady state value, firms switch their issuance of debt towards unsecured loans. Higher wages allow households to increase consumption, particularly consumption of relatively cheaper domestic goods, as well as increase equity investment in the banking system, which is used to finance additional loans to the production sector. The higher profitability of the production sector results in an improvement in credit conditions and a sharp decline in NPLs. Government

\footnotetext{
${ }^{8}$ The size of the shocks is as obtained from the estimation in Andreev et al. (2019): 13.5\% for oil price shock and 3.5\% for TFP shock.

${ }^{9}$ The cost of collateral here represents the shadow value of the capital value in the collateral constraint implied by the Lagrange multiplier.
} 
consumption rises due to the depreciation of the exchange rate, increasing the domestic value of foreign oil revenues.

The inflationary response reflects the lower real price of domestic output, which is a major factor in the depreciation of the currency, resulting in reductions in inflation and the nominal interest rate.

\subsubsection{Oil price shock}

A shock to the international oil price causes a sharp appreciation in the exchange rate ${ }^{10}$ leading to a corresponding large increase in imports. The stronger exchange rate leads to a reduction in the cost of imported goods for capital goods, and hence a fall in the price of capital. This causes an increase in the production of domestic non-tradeable goods. In contrast to a TFP shock, where the price of capital increases but is absorbed by higher productivity, here the decline in the price of capital temporarily stimulates production but is not enough to create efficiency gains and higher total income. The decline in the price of capital reduces the ability to issue secured debt, and consequently, the higher demand for investment is financed through the issuing of unsecured debt. Households switch from domestic savings in equity to foreign bonds to finance imported consumption, resulting in lower labour supply in subsequent periods. This causes a decline in the production of domestic non-tradeables in the medium term and is evidence of a Dutch disease-type effect in Russia: an increase in the tradeable sector causes the non-tradeable sector to contract as a result of the price of inputs, here labour. ${ }^{11}$ The decline in the interest rate on unsecured debt causes credit conditions to improve and the rate of non-performing loans to decline. This effect is pronounced in our model because of the strong substitution between domestic and foreign consumption goods driven by the high elasticity of the real exchange rate with respect to the dollar price of oil. Our evidence for this effect is consistent with Malakhovskaya and Minabutdinov (2014), but contradicts Kreptsev and Seleznev (2017) and Kozlovtceva et al. (2019). One reason for this is that our foreign interest rate does not depend explicitly on the dollar oil price, as in the case of Kreptsev and Seleznev (2017) and Kozlovtceva et al. (2019). This means that, as our foreign interest rate does not decrease when oil prices increase, households have a greater incentive to accumulate foreign assets and sustain their consumption of imports in the future. Another reason for our stronger Dutch disease effect is that oil revenue is given directly to the government, which spends it, and as a result aggregate demand depends directly and strongly on the domestic price of oil, which falls due to a strongly appreciating exchange rate. Government

\footnotetext{
10 The income shock stimulates demand for domestic goods while the exchange rate adjusts to reflect the substitution effect for imported goods and foreign savings.

${ }^{11}$ In the original Dutch disease, growth in the tradable sector causes an increase in demand for labour and hence higher wages, which causes the non-tradable sector to become unprofitable and contract. We find that the non-tradable sector contracts because the income effect due to the more profitable tradable sector causes a reduction in labour supply and higher wages.
} 
spending will not adjust as much as this in practice. However, in our model, government spending substitutes for a hand-to-mouth consumer whose consumption depends directly on domestic currency oil revenues.

\subsection{Policy analysis}

Here we present IRFs following a positive oil price and TFP shock under different macroprudential policies. Andreev et al. (2019) demonstrate that these shocks account for much of the variation in the business cycle. We consider macroprudential rules of four types: a LAW rule, a deposit requirement rule, a LTV rule, and a capital adequacy rule. All of these rules respond to the deviation of unsecured loans from the steady state.

\subsubsection{Oil price shock}

Figures 3 and 4 (see pp. 26-27) give IRFs for a positive oil price shock under different macroprudential policies. The augmented Taylor rule that responds to growth in unsecured credit (the LAW policy) and the countercyclical capital adequacy requirement have the largest effect in stabilizing the immediate impact of the shock on GDP and consumption, although the LAW policy results in a larger and more prolonged medium-term decline in GDP. The LAW policy, in particular, has a stronger effect in preventing an initial decline in the real interest rate, and thus causes households to defer their immediate consumption demands to the future. The higher real interest rates under a LAW policy also cut the demand for loans, reducing capital accumulation and domestic production and cushioning the business cycle effects of the shock. This suggests that a LAW-type macroprudential policy could help to manage aggregate fluctuations.

Focusing on the banking system alone, the countercyclical capital adequacy policy leads to the greatest reduction in non-performing loans and the greatest increase in the equity buffer. However, the substitution of deposits for equity means that the cost of bank funding is not significantly affected (reflected in the secured and unsecured interest rate series), causing total loans and capital to rise, which further amplifies the effect on GDP of the oil price shock. The countercyclical LTV policy has a similarly dramatic effect on the banking system, causing large declines in total loans and bank equity. This causes a decline in capital invested. However, as the bank cost of capital is not affected, the real interest rate is also not affected and households do not change their labour supply, resulting in negligible effects on the real economy.

\subsubsection{TFP shock}

Figures 5 and 6 (see pp. 28-29) give IRFs for a positive TFP shock under different macroprudential policies. Unlike in the case of the oil price shock, 
here the LAW policy amplifies the initial response of GDP by sharply increasing real interest rates, resulting in the intertemporal substitution effect being dominated by the income effect for households and causing households to switch away from deposits towards consumption. However, after the shock, the substitution effect dominates and deposits rise, labour falls, and GDP converges to the steady state faster than under other policies. The countercyclical deposit requirement also amplifies the response of GDP but does not stabilize the financial sector as effectively as the LTV policy, which does a better job of stabilizing loans, NPLs, and bank equity. The countercyclical capital adequacy ratio performs similarly to the LAW policy, but does not affect the real interest rate as effectively and consequently has a minimal effect on the real economy. In our environment, a combination of the LAW and LTV policies would seem best suited to respond to a productivity shock.

\section{Sensitivity analysis}

In this section we consider the robustness of our macroprudential policies under different parameterizations of policy rules. We refer to the baseline model which corresponds to no macroprudential policy as 'BM'. Model 1 (C1, D1, LTV1, T1 for the capital adequacy, deposit requirement, loan-to-value, and lean-againstthe-wind monetary policy rules respectively) corresponds to the parameterization considered in Section 3.4. Model 2 (C2, D2, LTV2, T2 for the capital adequacy, deposit requirement, loan-to-value, and lean-against-the-wind monetary policy rules respectively) corresponds to a parameterization with a higher response to unsecured credit growth.

\subsection{Capital adequacy}

The capital adequacy rule concerns the capital adequacy ratio $\bar{k}^{\text {bank }}$, a dynamic variable, and regulates it based on equation (26). Our benchmark model corresponds to $\eta=0$, the $\mathrm{C} 1$ model parameterization corresponds to $\eta=0.5$, and $\mathrm{C} 2$ corresponds to $\eta=1$. Figures 7 and 8 (see p. 30) show the response of our key variables ${ }^{12}$ to different specifications of the policy rule. We find that increasing the sensitivity of the capital adequacy requirement to growth in unsecured lending results in significantly higher volatility in loans, deposits, and NPLs but slightly dampens the response of GDP. A higher risk weight encourages greater equity investment but also greater loan generation. A procyclical policy rule would dampen the fluctuations in the financial sector but exacerbate the fluctuations in the real sector, highlighting the trade-off between financial stability and stabilization of the business cycle.

\footnotetext{
12 The variables from which the model was estimated in Andreev et al. (2019).
} 


\subsection{Deposit requirement}

The deposit requirement regulation follows the rule in equation (24) with the baseline parameterization of $v$ taking the value of 0 , while in specification D1 (used in the previous section) this value is 0.15 and in the new specification, $\mathrm{D} 2$, it is 0.3 . As follows from Figures 9 and 10 (see p. 31), as in the case of the capital adequacy regulation, changing the parameterization has a minor effect on business cycle variables, but large effects on financial sector variables. When the requirement is more sensitive to unsecured credit growth, there is a dampening effect on deposits and NPLs, and, in the medium term, on total loans. In the short term, the effect on total loans is amplified, driven by an increase in deposits held as reserves.

\subsection{LTV ratio}

The loan-to-value macroprudential policy follows the rule in equation (25) where $\chi$ takes the value of 0 for the baseline specification, -0.5 for specification LTV1, and -1 for specification LTV2. In this rule, the effect on real variables is similar under specifications LTV1 and LTV2. The initial response of loans and deposits is amplified by the higher elasticity of the rule with respect to unsecured credit, although the effect on non-performing loans is dampened due to the switch from unsecured to secured credit.

\subsection{LAW}

The lean-against-the-wind type of Taylor rule is represented by equation (23) where $\varsigma$ is 0 in the baseline specification, 0.5 in specification T1, and 1 in specification T2. In Figure 13 (see p. 33), following an oil shock, we can see that the policy with the higher value of $\varsigma$ causes a greater initial response from financial variables but dampens GDP and consumption in the short run. In the medium term, the significantly greater deviation of interest rates from the steady state results in a larger effect on GDP, but dampens consumption and financial variables. Real and financial variables respond differently in each of the three specifications. The policy rate's heightened response to the growth in unsecured credit results in a greater reduction in both inflation and the nominal interest rate, which helps to stabilize GDP and consumption faster. Following a TFP shock, in Figure 14 (see p. 33), there is a greater initial response from GDP and consumption and financial sector variables, but a faster convergence to the steady state in the medium term. 
Figure 2. IRFs to a positive one-standard-deviation shock: oil price and TFP
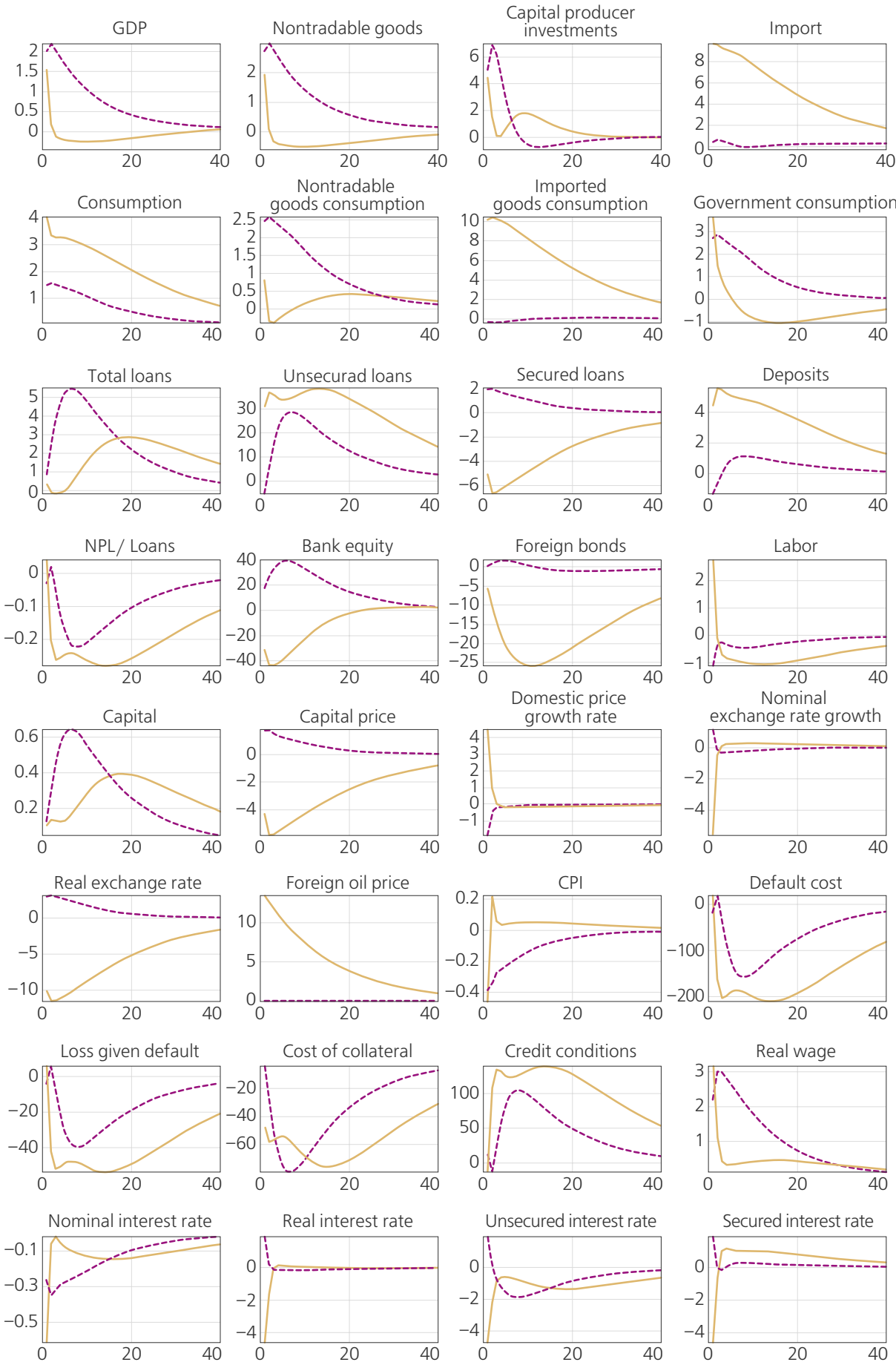

oil price shock

TFP shock 
Figure 3. IRFs to a positive one-standard-deviation oil price shock
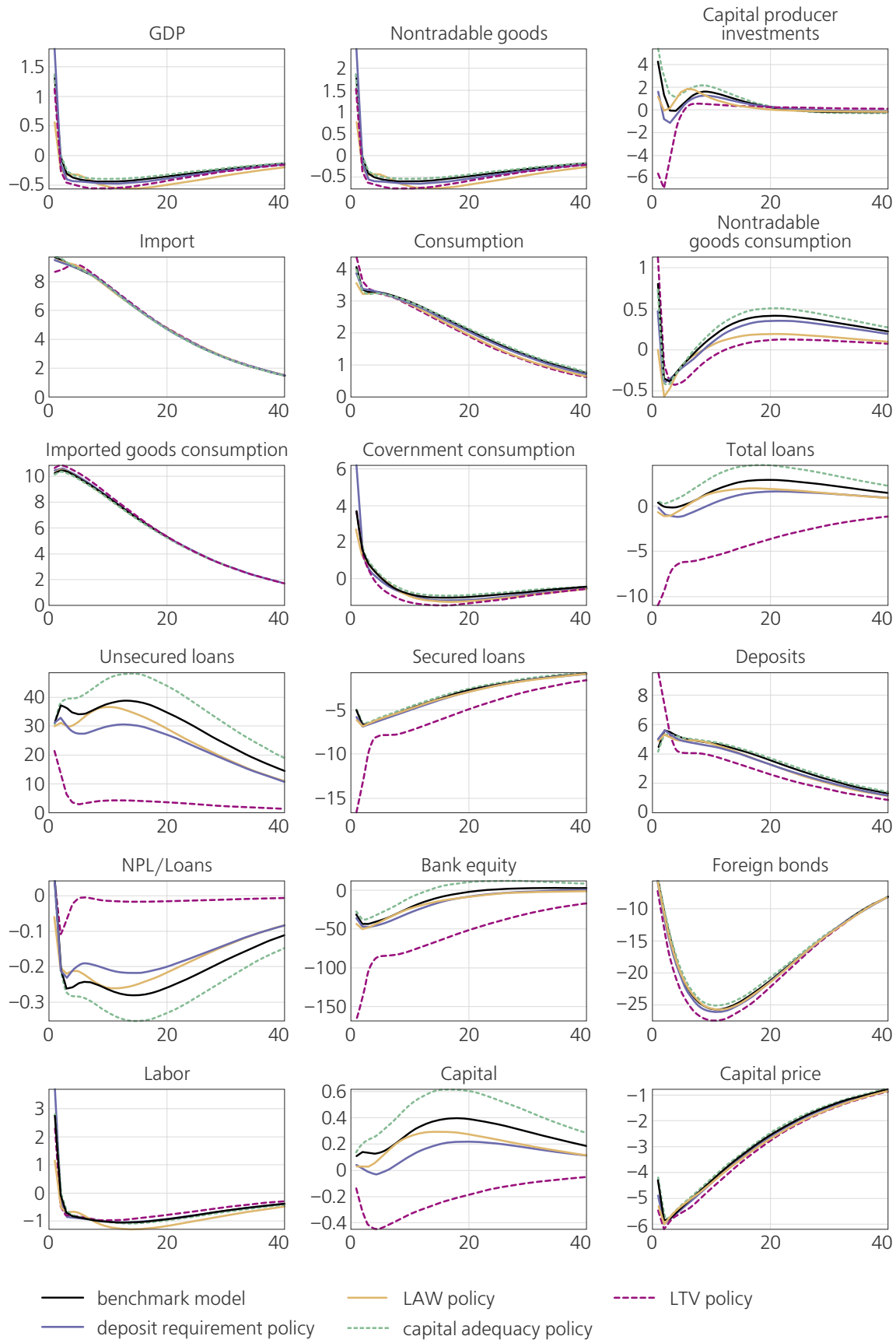

$$
\begin{aligned}
& \text { LAW policy } \\
& \text { capital adequacy policy }
\end{aligned}
$$$$
\text { - LTV policy }
$$ 
Figure 4. IRFs to a positive one-standard-deviation oil price shock
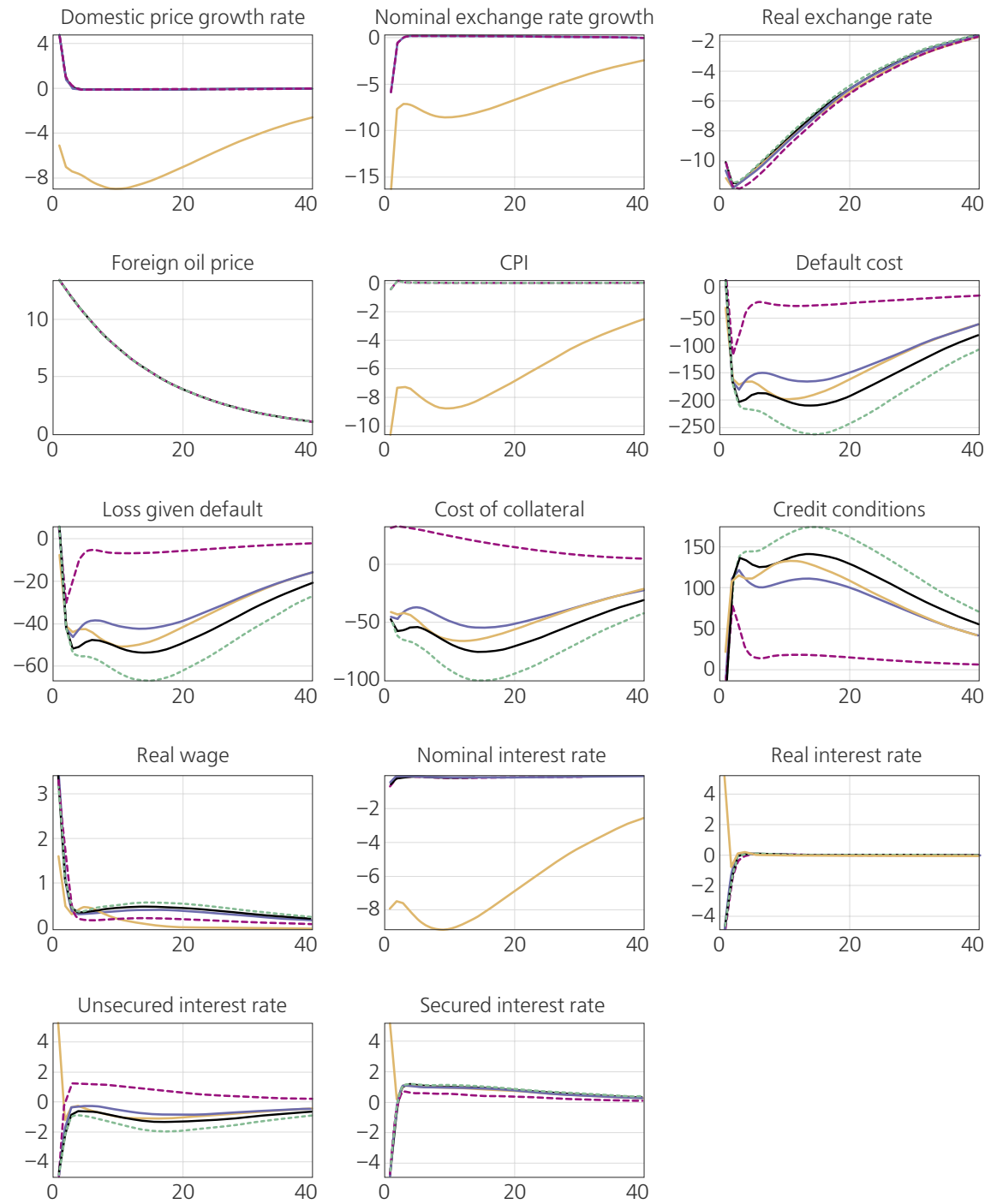

benchmark model

LAW policy

LTV policy

deposit requirement policy

capital adequacy policy 
Figure 5. IRFs to a positive one-standard-deviation TFP shock
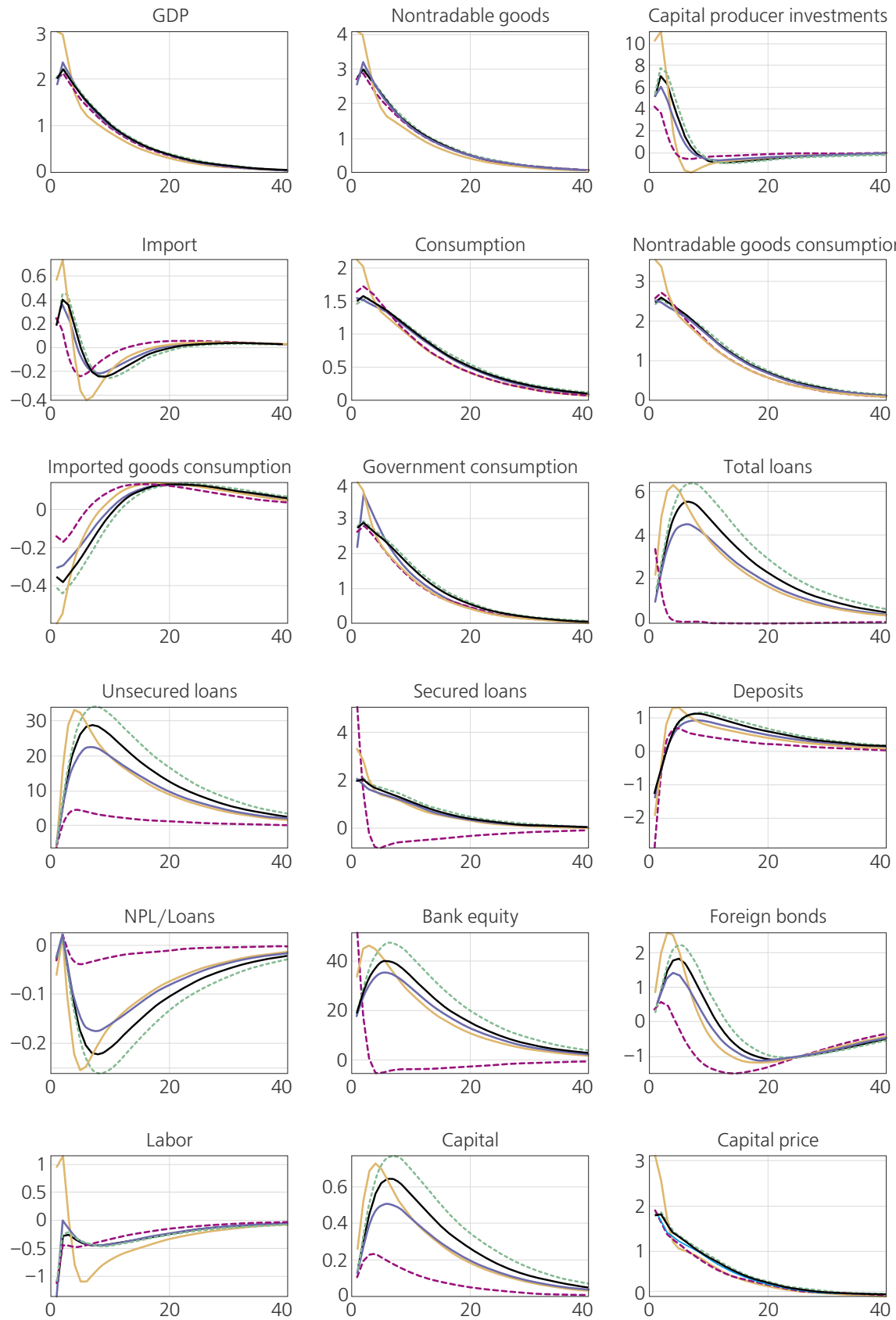

benchmark model

LAW policy

LTV policy

deposit requirement policy

capital adequacy policy 
Figure 6. IRFs to a positive one-standard-deviation TFP shock
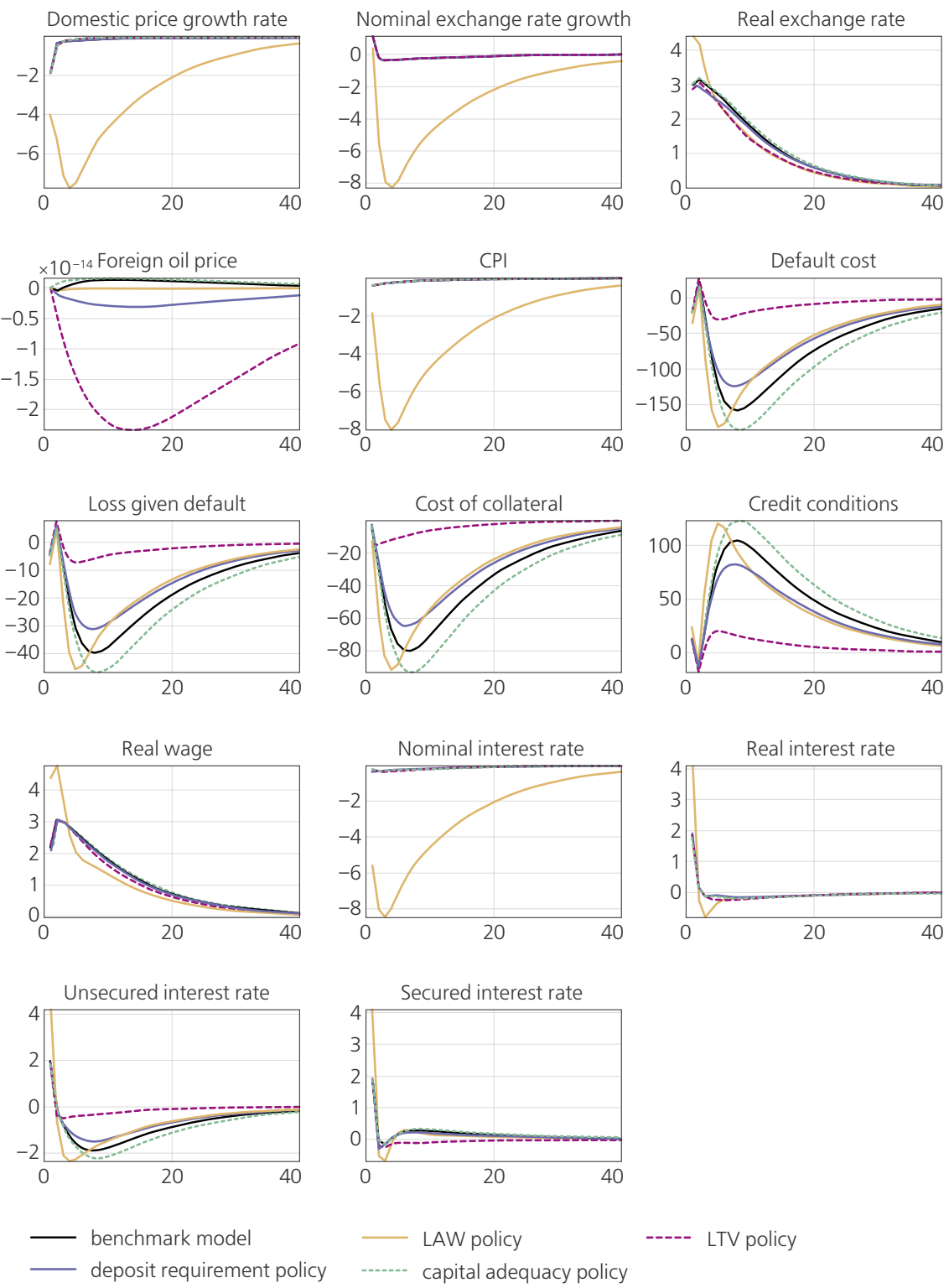
Figure 7. Robustness check on capital adequacy requirement policy for oil price shock
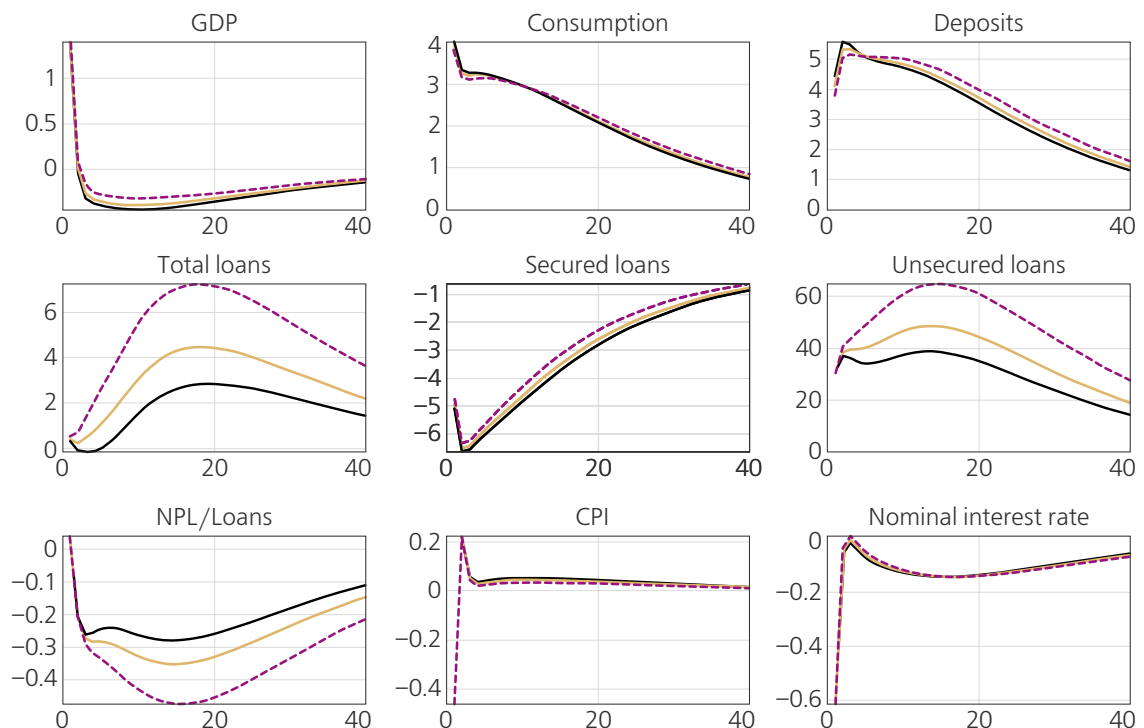

benchmark model (BM)

model with the first parameterization of capital adequacy policy (C1)

model with the second parameterization of capital adequacy policy (C2)

Figure 8. Robustness check on capital adequacy requirement policy for TFP shock
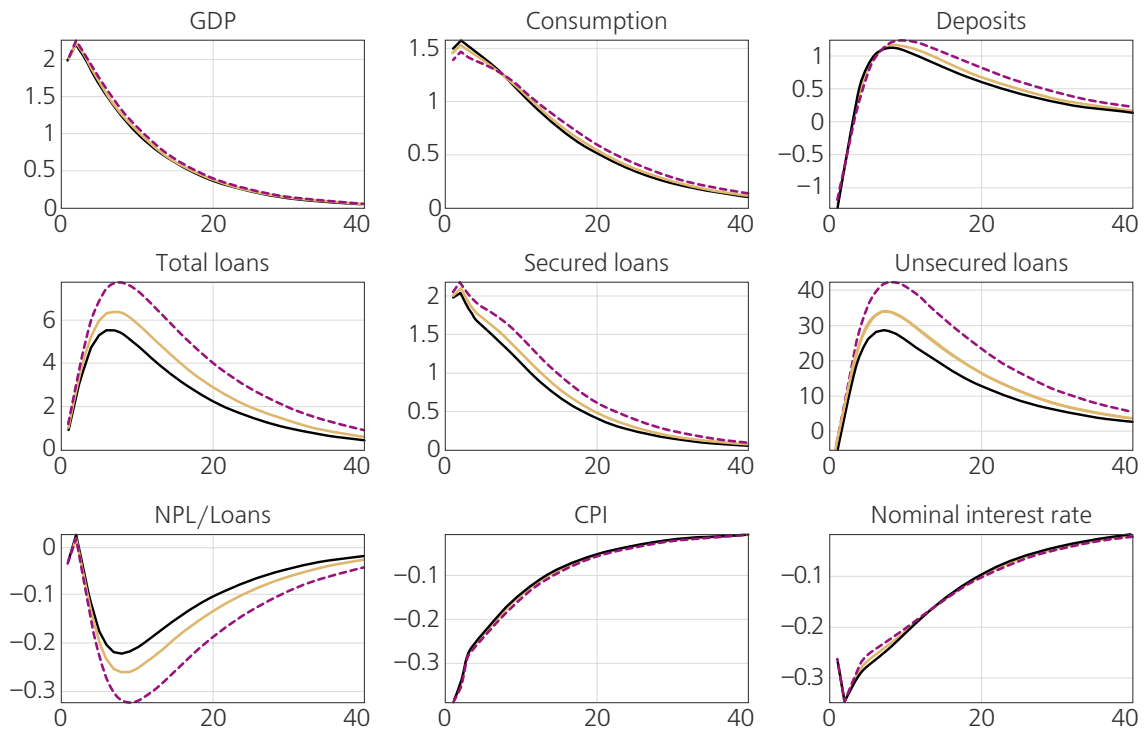

benchmark model (BM)

model with the first parameterization of capital adequacy policy (C1)

model with the second parameterization of capital adequacy policy (C2) 
Figure 9. Robustness check on deposit requirement policy for oil price shock
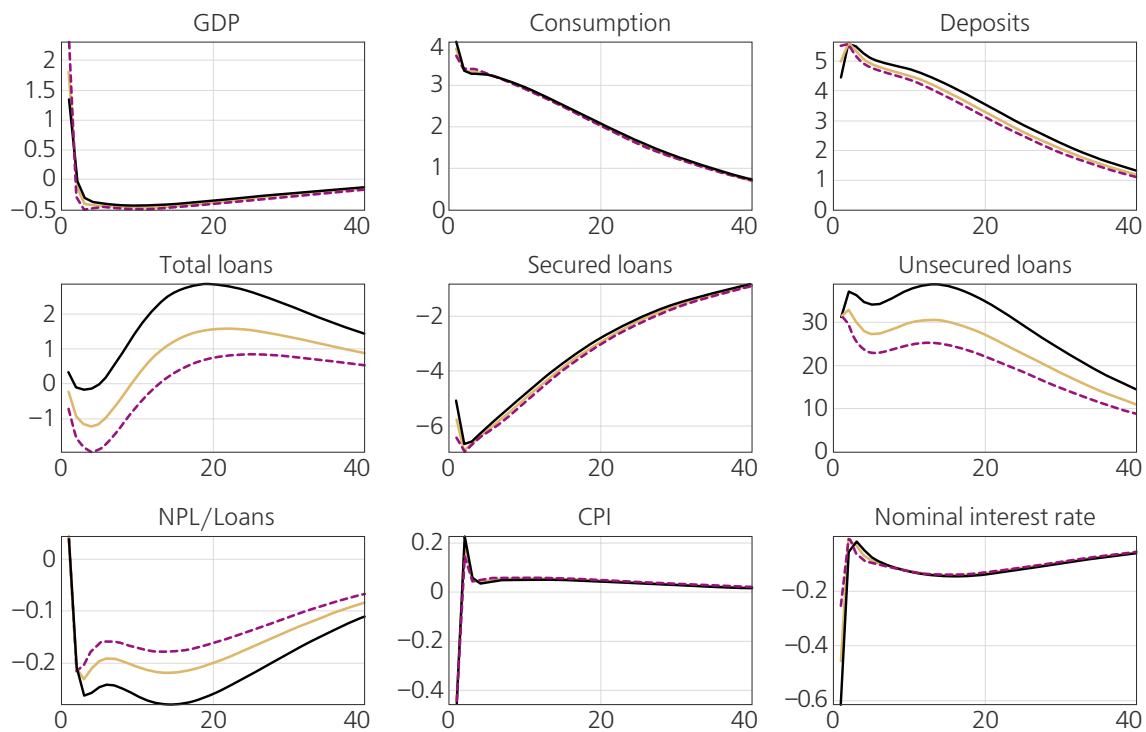

— benchmark model (BM)
- model with the first parameterization of deposit requirement policy (D1)

Figure 10. Robustness check on deposit requirement policy for TFP shock
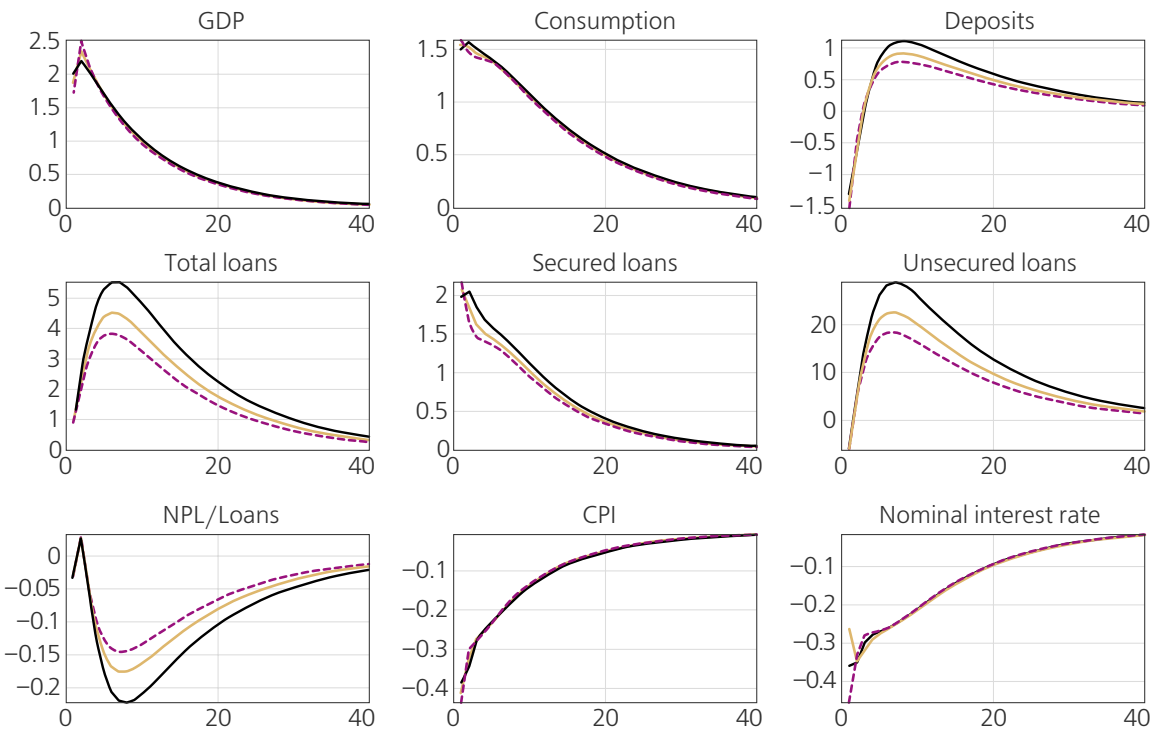

benchmark model (BM) model with the first parameterization of deposit requirement policy (D1) model with the second parameterization of deposit requirement policy (D2) 
Figure 11. Robustness check on LTV ratio policy for oil price shock
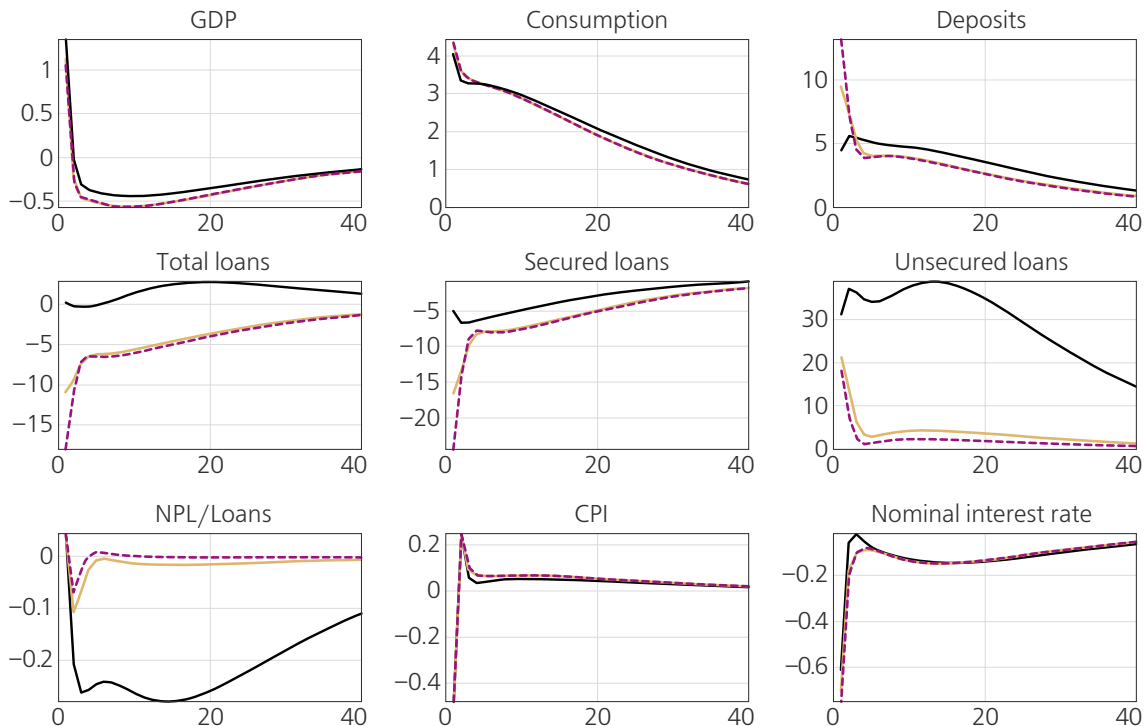

- benchmark model (BM)

_ model with the first parameterization of LTV ratio policy (LTV1)

----- model with the second parameterization of LTV ratio policy (LTV2)

Figure 12. Robustness check on LTV ratio policy for TFP shock
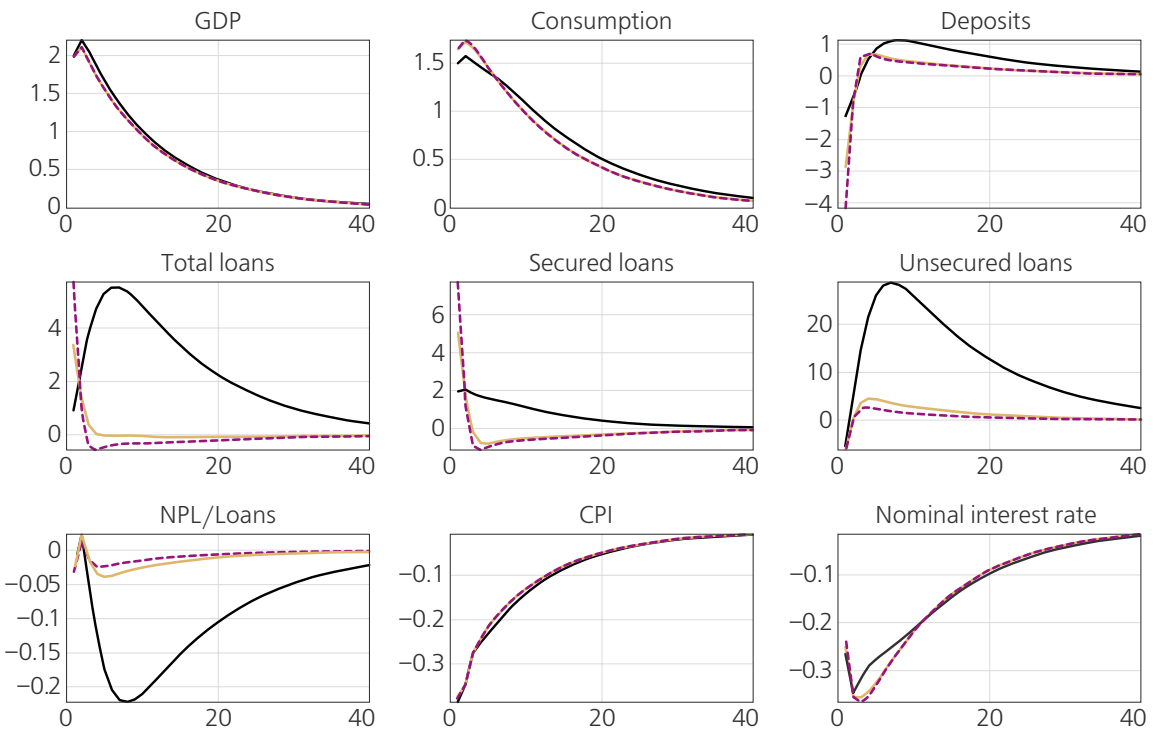

— benchmark model (BM)

— model with the first parameterization of LTV ratio policy (LTV1)

----- model with the second parameterization of LTV ratio policy (LTV2) 
Figure 13. Robustness check on LAW policy for oil price shock
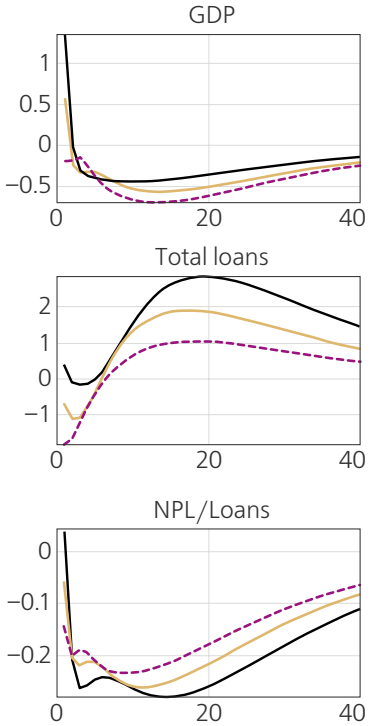

- benchmark model (BM)

- model with the first parameterization of LAW policy (T1)

----- model with the second parameterization of LAW policy (T2)

\section{Figure 14. Robustness check on LAW policy for TFP shock}
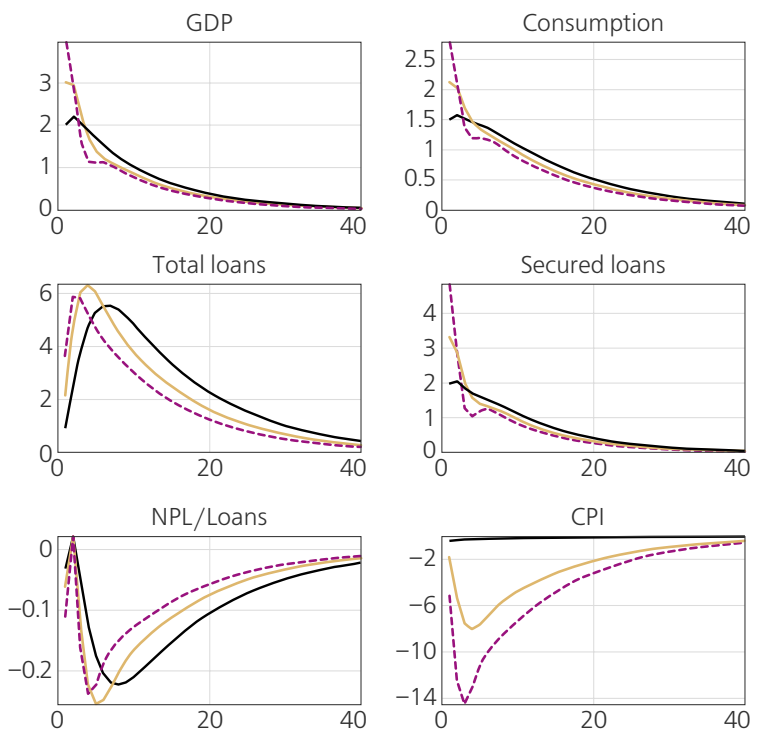

- benchmark model (BM)
- model with the first parameterization of LAW policy (T1)

- benchmark model (BM)
- model with the first parameterization of LAW policy (T1)

- benchmark model (BM)
- model with the first parameterization of LAW policy (T1)
---- model with the second parameterization of LAW policy (T2)
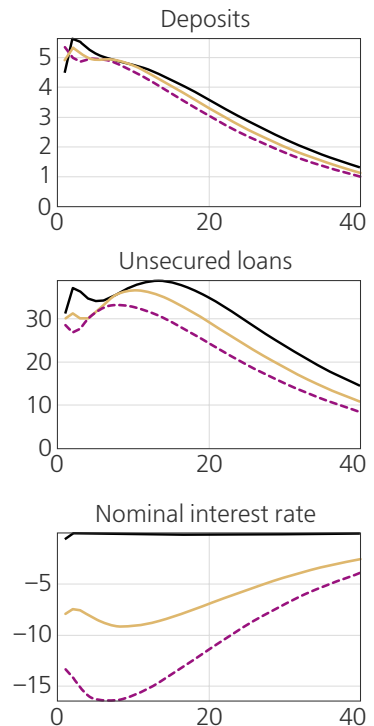
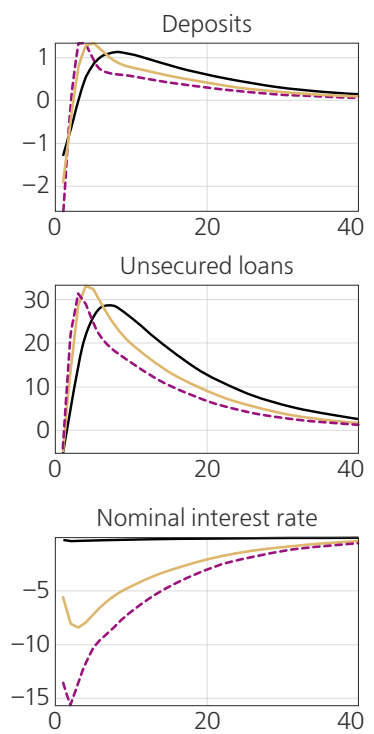


\section{Concluding remarks}

In this paper we developed a New Keynesian model of a small open economy with a banking sector and secured and unsecured debt. We calibrated the model to the parameters found in Andreev et al. (2019), which also found that the Russian business cycle is dominated by shocks to the foreign price of oil and TFP. We compared the effectiveness of an unsecured credit-augmented Taylor rule, a countercyclical deposit requirement, a LTV ratio, and capital adequacy requirements in stabilizing the economy in the event of oil price and TFP shocks. In line with the findings of Kozlovtceva et al. (2019), we find that a LAW monetary policy has the potential to play the greatest stabilizing role following both shocks, but may need to be implemented in conjunction with policies such as the countercyclical deposit reserve requirement and LTV ratio policies for oil and TFP shocks respectively. The optimal combination of policies and in particular the welfare implications of policies, as discussed in Kashyap et al. (2017), are important considerations which are left to subsequent work.

\section{References}

Adolfson, M., Lasèen, S., Christiano, L., Trabandt, M. and Walentin, K. (2013). Ramses II - Model Description. Sveriges Riksbank Occasional Paper Series, N 12.

Aikman, D., Bridges, J., Kashyap, A. and Siegert, C. (2019).

Would Macroprudential Regulation Have Prevented the Last Crisis? Journal of Economic Perspectives, 33(1), pp. 107-30. doi: 10.1257/jep.33.1.107

Andreev, M., Peiris, M. U., Shirobokov, A. and Tsomocos, D. P. (2019). Commodity Cycles and Financial Instability in Emerging Economies. Mimeo.

Berben, R.-P., Bierut, B., van den End J. W. and Kakes, J. (2010). Macro-Effects of Higher Capital and Liquidity Requirements for Banks. DNB Occasional Studies, 8(3).

Borio, C. and Zhu, H. (2012). Capital Regulation, Risk-Taking and Monetary Policy: A Missing Link in the Transmission Mechanism? Journal of Financial Stability, 8(4), pp. 236-251.

Brzoza-Brzezina, M., Kolasa, M. and Makarski, K. (2013). The Anatomy of Standard DSGE Models with Financial Frictions. Journal of Economic Dynamics and Control, 37(1), pp. 32-51.

Christiano, L. J., Eichenbaum, M. S. and Trabandt, M. (2015). Understanding the Great Recession. American Economic Journal: Macroeconomics, 7(1), pp. 110-167. doi: $10.1257 /$ mac.20140104

Christiano, L., Motto, R. and Rostagno, M. (2010). Financial Factors in Economic Fluctuations. ECB Working Paper, N 1192.

Cúrdia, V. and Woodford, M. (2010). Credit Spreads and Monetary Policy. Journal of Money, Credit and Banking, 42(s1), pp. 3-35. doi:10.1111/j.1538-4616.2010.00328.x

De Moraes, C. O., Montes, G. C. and Antunes, J. A. P. (2016). How Does Capital Regulation React to Monetary Policy? New Evidence on the Risk-Taking Channel. Economic Modelling, 56, pp. 177-186. doi: 10.1016/j.econmod.2016.03.025 
De Walque, G., Pierrard, O. and Rouabah, A. (2010). Financial (In)Stability, Supervision and Liquidity Injections: A Dynamic General Equilibrium Approach. Economic Journal, 120(549), pp. 1234-1261. doi: 10.1111/j.1468-0297.2010.02383.x

Dubey, P., Geanakoplos, J. and Shubik, M. (2005). Default and Punishment in General Equilibrium. Econometrica, 73(1), pp. 1-37. doi: 10.1111/j.1468-0262.2005.00563.x

Eichner, M., Kohn, D. L. and Palumbo, M. G. (2013). Financial Statistics for the United States and the Crisis: What Did They Get Right, What Did They Miss, and How Could They Change? In: C. R. Hulten and M. B. Reinsdorf, eds. Measuring Wealth and Financial Intermediation and Their Links to the Real Economy. University of Chicago Press, pp. 39-66.

Erceg, C. J., Henderson, D. W. and Levin, A. T. (2000). Optimal Monetary Policy with Staggered Wage and Price Contracts. Journal of Monetary Economics, 46(2), pp. 281-313.

Gale, D. (2010). Capital Regulation and Risk Sharing. International Journal of Central Banking, 6(4), pp. 187-204.

Gambacorta, L. and Shin, H. S. (2016). Why Bank Capital Matters for Monetary Policy. Journal of Financial Intermediation, 35(B), pp. 17-29.

Gavalas, D. (2015). How Do Banks Perform under Basel III? Tracing Lending Rates and Loan Quantity. Journal of Economics and Business, 81, pp. 21-37.

Ghosh, S. (2008). Capital Requirements, Bank Behavior and Monetary Policy A Theoretical Analysis with an Empirical Application to India. Indian Economic Review, pp. 205-227.

Goodhart, C. A. E., Peiris, M. U. and Tsomocos, D. P. (2018). Debt, Recovery Rates and the Greek Dilemma. Journal of Financial Stability, 36, pp. 265-278.

Goodhart, C. A. E., Sunirand, P. and Tsomocos, D. P. (2005). A Risk Assessment Model for Banks. Annals of Finance, 1(2), pp. 197-224.

Goodhart, C. A. E., Sunirand, P. and Tsomocos, D. P. (2006). A Model to Analyse Financial Fragility. Economic Theory, 27(1), pp. 107-142.

Gourio, F., Kashyap, A. K. and Sim, J. W. (2018). The Trade Offs in Leaning Against the Wind. IMF Economic Review, 66(1), pp. 70-115. doi: 10.1057/s41308-017-0043-3

Ivashchenko, S. (2013). Dynamic Stochastic General Equilibrium Model with Banks and Endogenous Defaults of Firms. Journal of the New Economic Association, 19(3), pp. 27-50. [In Russian]. Available at: http://www.econorus.org/repec/journl/2013-1927-50r.pdf [accessed on 2 August 2019].

Kashyap, A. K., Tsomocos, D. P. and Vardoulakis, A. P. (2017). Optimal Bank Regulation in the Presence of Credit and Run Risk. Said Business School Research Papers, N 17.

Kozlovtceva, I., Ponomarenko, A., Sinyakov, A. and Tatarintsev, S. (2019). Financial Stability Implications of Policy Mix in a Small Open Commodity-Exporting Economy. Bank of Russia Working Paper Series, N 42. Available at: http://cbr.ru/Content/ Document/File/72596/wp42_e.pdf [accessed on 2 August 2019].

Kreptsev, D. and Seleznev, S. (2017). DSGE Model of the Russian Economy with the Banking Sector. Bank of Russia Working Paper Series, N 27. 
Malakhovskaya, O. and Minabutdinov, A. (2014). Are Commodity Price Shocks Important? A Bayesian Estimation of a DSGE Model for Russia. International Journal of Computational Economics and Econometrics, 4(1/2), pp. 148-180. doi: 10.1504/IJCEE.2014.060294

Martinez, J. F. and Tsomocos, D. P. (2018). Liquidity and Default in an Exchange Economy. Journal of Financial Stability, 35, pp. 192-214. doi: 10.1016/j.jfs.2016.10.010

Nachane, D. M., Ghosh, S. and Ray, P. (2006). Basel II and Bank Lending Behaviour: Some Likely Implications for Monetary Policy. Economic and Political Weekly, 41(11), pp. 1053-1058.

Peiris, M. U. and Tsomocos, D. P. (2015). International Monetary Equilibrium with Default. Journal of Mathematical Economics, 56, pp. 47-57.

Polbin, A. (2014). Econometric Estimation of the Structural Macro Model of Russian Economy. Applied Econometrics, 33(1), pp. 3-29. [In Russian]. Available at: http://pe.cemi.rssi.ru/pe_2014_1_03-29.pdf [accessed on 2 August 2019].

Roch, F. and Uhlig, H. (2016). The Dynamics of Sovereign Debt Crises and Bailouts. IMF Working Papers, N 136.

Shubik, M. and Wilson, C. (1977). The Optimal Bankruptcy Rule in a Trading Economy Using Fiat Money. Zeitschrift Für Nationalökonomie / Journal of Economics, 37 (3/4), pp. 337-354.

Taylor, J. B. (1993). Discretion versus Policy Rules in Practice. Carnegie-Rochester Conference Series on Public Policy, 39, pp. 195-214. doi: 10.1016/0167-2231(93)90009-L

Tsomocos, D. P. (2003). Equilibrium Analysis, Banking and Financial Instability. Journal of Mathematical Economics, 39(5-6), pp. 619-655.

Walsh, K. J. (2016). Portfolio Choice and Partial Default in Emerging Markets: A Quantitative Analysis. Available at: https://sites.google.com/site/kieranjameswalsh/ research [accessed on 2 August 2019] 


\section{APPENDIX}

Table 6. Corporate loans in Russia: secured and unsecured

\begin{tabular}{lcc} 
Type of loan & Raiffeisen (2017) & Moscow Credit Bank (2016) \\
\hline Unsecured loans & $50.3 \%$ & - \\
\hline Guarantees & $24.5 \%$ & - \\
\hline Total uncollaterized & $74.8 \%$ & $56.2 \%$ \\
\hline Real estate & $18.1 \%$ & $16.9 \%$ \\
\hline Other & $7.1 \%$ & $26.9 \%$ \\
\hline Total collaterized & $25.2 \%$ & $43.8 \%$ \\
\hline
\end{tabular}

